
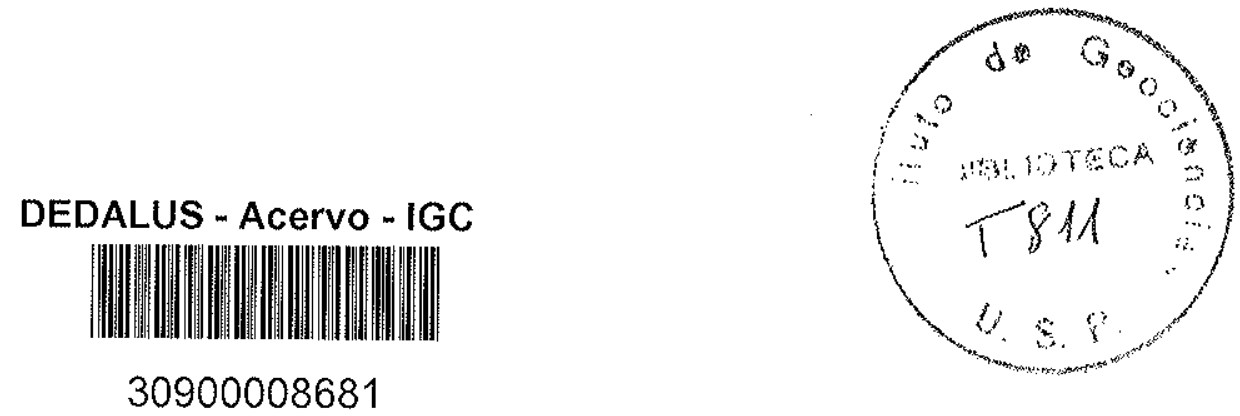

\title{
ESTUDO MINERALOGICO DE CLINQUER DE CIMENTO PORTLAND
}

Dissertação de Mestrado apresentada ao Instituto de Geociências da

Universtdade de São Paulo 
II - IR E I W D

III - II $\operatorname{Tr}$ IR $Q \mathrm{O}$ D

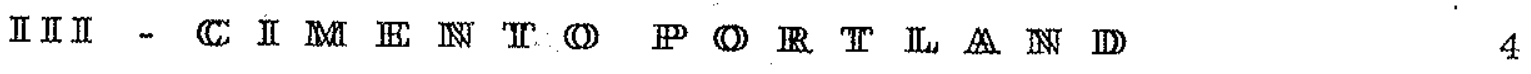

1. DEFINIÇOES

2. FABRICAÇAO 4

3. TERMOQUIMICA 9

4. COMPONENTES 13

II W - $\quad$ C

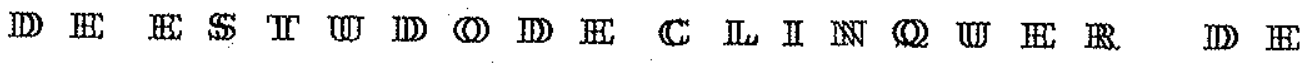

CE II IE IN II

1. GENERALIDADES 18

2. METODOLOGIA 19

3. ESTUDOS MICROSCOPICOS 23

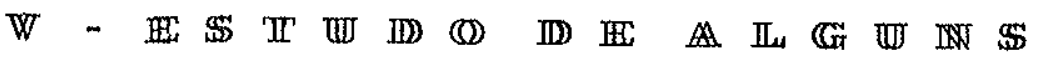

C IM II $\mathbb{N} Q$ W

1. OBSERVAÇOES DOS ESTUDOS MICROSCOPICOS 31

2. POROSIDADE 37

3. COMPOSIÇAOMODAL 37

4. ANÁLISES QUÍMICAS 38

5. COMPOSIÇAO NORMATIVA (BOGUE) 39

6. MODULOS DE CLINQUERES 42

WII - $\mathbb{C} O \mathbb{N} \mathbb{N}$ II $\mathbb{D}$ 正

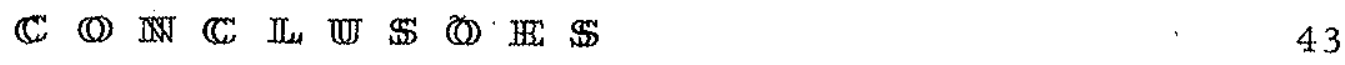

1. SOBRE AS ANÁLISES MODAIS E NORMATTVAS 43

2. SOBRE A MATÉRIA PRIMA $\quad 52$

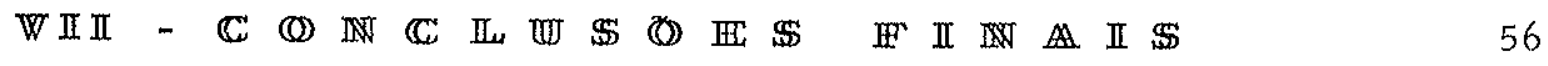

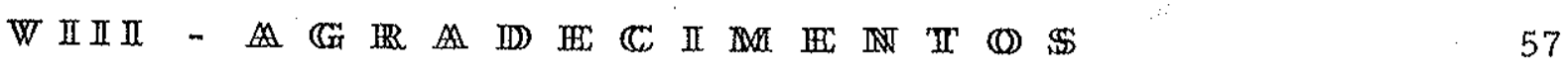

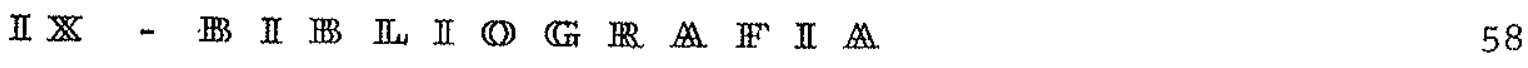

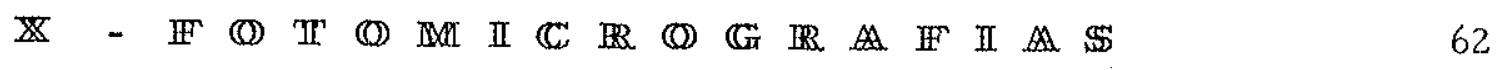


O presente trabalho apresenta os resultados de estudos mineralógicos de seis clinqueres de cimento Portland produzidos comercialmente por industrias nacionais, com matérias primas domésti cas.

Esses seis exemplos representam, em verdade, uma sem leção de numerosos produtos analisados, por se prestarem melhor às diagnoses dos tipos, condições de preparaçâo e cuidados no contrôle da matéria prima, bem como dos processos de clinquerização e de resfriamento.

A parte fundamental deste estudo é desenvolvida por mi croscopia óptica. Para êsse fim são descritas, minuciosamente, as técnicas de amostragem e de preparação das amostras (seções poli das), assim como o uso de reagentes seletivos ("spot test") para identificação das fases presentes:

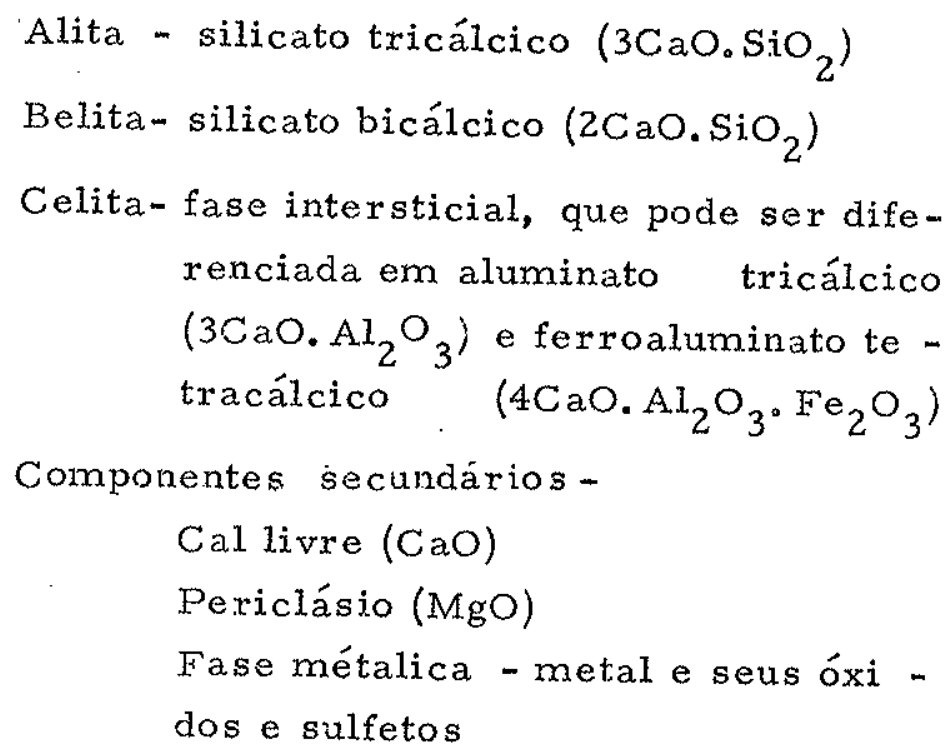

O presente estudo é corroborado por análises químicas, que constituem base para a determinação da composição "mineralógi ca" normativa através dos cálculos propostos por Bogue.

Baseados nos conceitos termodinâmicos de equilíbrio entre as fases presentes nos clínqueres, aliados a conceitos mineraló- 
gicosmcristalográficos (difusão iônica, reações de estado sólido, solu ções sólidas, crescimento cristalino, etc) e a critérios petrográficos (estrutura e textura), o estudo microscópico fornece informações som bre:

- Composição, granulometria e homogeneidade da matéria prima (calcáreo e argila);

- temperatura e tempo de clinquerização; e,

- velocidade de resfriamento do clinquer.

E feita uma comparação entre a análise modal obtida por microscopia e a análise normativa calculada a partir das análises químicas, evidenciando as vantagens diagnósticas do método mi croscópico para definir a composição do clinquer.

Conclue-se que:

1. As análises químicas são imprescindíveis no contrö le rotineiro da matéria prima, permitindo correções imediatas na sua composição. Elas definem ainda, su pondo-se um processamento industrial adequado, os módulos de hidraulicidade, de sílica e de fundentes do clinquer.

2. A microscopia, através do estudo das relações para genéticas e texturais e do estabelecimento de uma composição modal, constitue um excelente método de semi-rotina para o contrôle de fabricação industrial do clinquer, fornecendo, implicitamente, recomendaçōes para melhorar a sua qualidade. 


\section{II - II IN $\mathbb{I I}^{\mathrm{I}}$ (O) ID WU}

O clinquer de cimento Portland pode, em primeira apro ximação, sex correlacionado ao produto do processo geológico de metamorfismo de alto grau de sedimentos calcáreos e argilosos, onde ocorrem: reações no estado sólido entre os seus constituintes, rea ção destas fases formadas com a fusão de parte variável de sua mas sa, formação de minerais, e transformações mineralógicas por efei to do resfxiamento. Assim, a fabricação de cimento simula a coexistência de um magma com xenólitos instáveis à alta temperatura, ten dendo a estabelecer um equilíbrio entre seus constituintes mineralógicos através de reações de estado sólido, e um equilibrio entre os sólidos e a parte fundida, através de trocas catiônicas.

O estudo microscópico desse produto, utilizando-se das observações estruturais, texturais e mineralógicas, fornece indicações das condições de formação das fases constituintes do clinquer, assim como um estudo petrográfico possibilita informações sobreas condições de formação dos minerais nas rochas.

Estas informações concernem:

a) as características do material de partida (calcáreo e argila) quanto à composição mineralógica, composição química, homogeneidade e granulometria;

b) as condições de aquecimento: rápido ou lento, 'por períodos curtos ou prolongados;

c) as condições limites de temperatura atingida; e,

d) as condições de resfriamento.

Neste trabalho tentar-se-á provar que os dados obtidos no estudo microscópico refletem a tecnologia de fabricação, a qualidade do produto industrial obtido e induzem a sugestões para a sua melhoria, por alterações das características do material de parti da e por mudanças nas condições de aquecimento e resfriamento. 
Conhecendo-se os problemas ligados à fabricação do cimento Portland efetuou-se o estudo microscópico de 6 clinqueres bra sileiros, interpretando sua estória térmica através de suas caracte rísticas mineralógicas, fornecendo-se ao mesmo tempo, indicações de natureza tecnológica e sugestões para a sua melhoria.

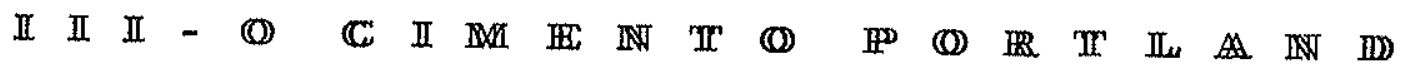

\section{DEFINIÇOES}

Clinquer de cimento Portland pode sex definido como um produto granulado, obtido por tratamento térmico até o abrandamento e sintexização de mistura adequada de calcáreo e argila. Ém pro duto constituído na sua maiox parte por silicatos cálcicos (75\%) e em proporções menores de aluminatos e ferroaluminatos cálcicos. Es sas fases são obtidas à partir do aquecimento até a fusão parcial (clinquerização) da mistura de argila e calcáreo, dosada de manei ra a constituix uma proporção conveniente de cal ( $\mathrm{CaO})$, sílica $\left(\mathrm{SiO}_{2}\right)$ e de proporções menores de alumina $\left(\mathrm{Al}_{2} \mathrm{O}_{3}\right)$ e óxido de ferro $\left(\mathrm{Fe}_{2} \mathrm{O}_{3}\right)$.

Cimento Portland é um aglomerante hidráulico obtido pela moagem do clinquer portland com adição, durante a moagem, de pequena quantidade de sulfato de cálcio para regular o tempo de iní cio de hidratação dos componentes do cimento (tempo inicial de pega).

\section{FABRICAÇAO DE CIMENTO PORTLAND}

A fabricação de cimento Poxtland envolve um conjunto de operações (Fig. 1) que pode ser resumido nas seguintes etapas:

2.1. Moagem

A preparação da mistura crua ("cru") consiste no trata -mento da matéria prima (calcário e argila) nos britadores e moinhos 


\section{FABRICAGAO DE CIMENTO PORTLAND}

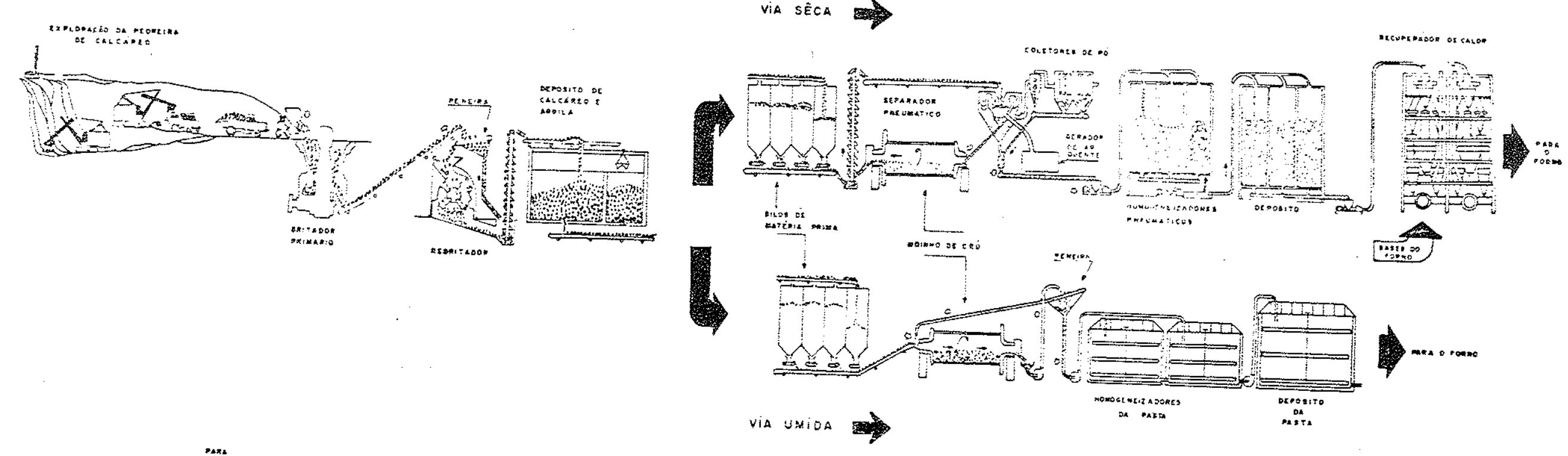

VIA SËCA
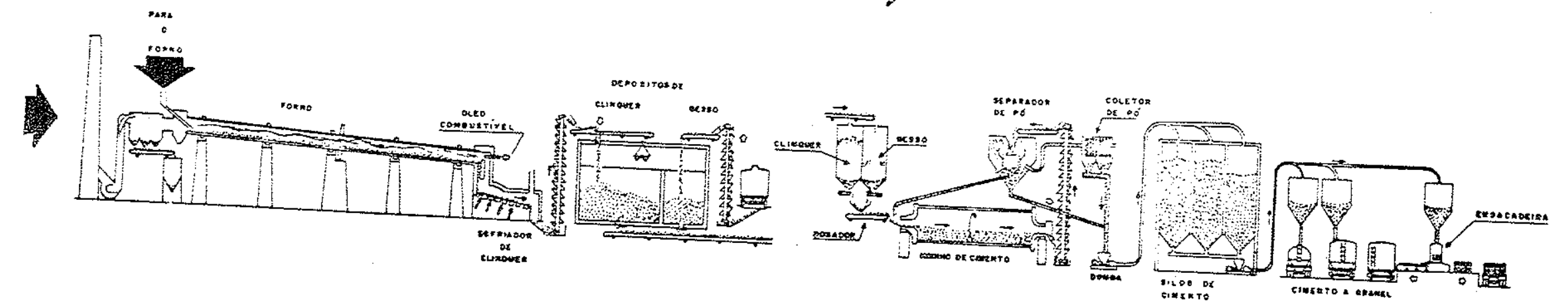

FIGURA I 
de bola, para que seja reduzida à granulaçãc média de 0,050 mm ( 50 micra).

A granulometria do "cru", tem papel muito importante na cinética das reações de clinquerizậão. Não se pode precisar a granulometria ideal, pois ela varia de material para material, depen dendo de suas características mineralógicas e estruturais. KRAMER (1957) verificou que calcário compacto de granulação fina reage me-nos que um cálcario menos coerente e poroso e de granulação fina. Observou que para cálcarios compactos e quartzo cristalizado o limite de granulação é de 100 micra. As argilas normalmente não apresentam problemas de granulação devido ao seu diâmetro menor que 2 micra.

Ao mesmo tempo que o material é submetido à moagem, inicia-se a mistura da matéria prima. Conforme o processo, a moa gem é feita na presença ou na ausência de água ("via úmida" ou "via sêca"l).

\subsection{Dosagem da mistura "crua"}

Consiste no contrôle químico dos elementos presentes pa ra a obtenção de um cimento Portland de composição desejada.

Durante o processo de fabricação de cimento, a compo sição, a proporção, a granulometria e a homogeneização tanto da matéria prima como da mistura crua são rigorosa e periodicamente controladas. Sobretudo no processo de via sêca, exige-se o controle químico contínuo e preciso da matéria prima e da mistura crua. Por esse motivo empregam-se métodos analíticos como da espectrografia de raios $-X$.

Para o controle e dosagem da mistura crua os seguin tes parâmetros såo os mais utilizados:

a) o módulo de hidraulicidade (MH) relaciona a cal com os componentes ácidos, expressos em porcentagem ponderal. Tem seus valores normais estabeleci dos entre $1,7<M H<2,2$; sendo 2 o valor ótimo. 


$$
\mathrm{MH}=\frac{\mathrm{CaO}}{\mathrm{SiO}_{2}+\mathrm{Al}_{2} \mathrm{O}_{3}+\mathrm{Fe}_{2} \mathrm{O}_{3}}
$$

b) o módulo de sílica (MS) relaciona a sílica com os fun dentes, expressos em porcentagem ponderal. Os $1 i$ mites estabelecidos são os seguintes: $1,2<\mathrm{MS}<4,0$; sendo os valores compreendidos entre 2,4 e 2,7 con siderados ideais.

$$
\mathrm{MS}=\frac{\mathrm{SiO}_{2}}{\mathrm{Al}_{2} \mathrm{O}_{3}+\mathrm{Fe}_{2} \mathrm{O}_{3}}
$$

c) o módulo de alumina-ferro ou de fundentes (MAF) re laciona a alumina com o óxido de ferro, expressos em porcentagem ponderal. Tem importância na fabri cação e no tipo de cimento produzido. Os limites estabelecidos são os seguintes: $1<M F<4$; $\quad$ sendo ideal entre 1, 4 e 2,5. Em cimentos brancos o $M F$ atinge valores máximos.

$$
\mathrm{MF}=\frac{\mathrm{Al}_{2} \mathrm{O}_{3}}{\mathrm{Fe}_{2} \mathrm{O}_{3}}
$$

\section{3. Homogeneização da mistura crua}

A mistura crua devidamente dosada e com a finura ade quada, deve tex a sua homogeneização assegurada para permitir, na clinquerização, uma perfeita combinação dos elementos formadores dos componentes de clinquer.

No processo de fabricação por via úmida, o meio dispexsante para misturar a matéria prima, a água, é adicionada nos moinhos de bola. A pasta formada, com cêrca de 35 a $45 \%$ de água, é bombeada aos tanques de homogeneização, onde durante horas, pox meio de pás mecânicas é fetta a homogeneização. A pasta é contro lada quimicamente e, quando necessário, a sua composição é corrigịa. 
No processo de fabricação por via sêca, o meio disper sante é o ar. A matéria prima, já misturada, sai do moinho e é transportada aos silos de homogeneização, onde é necessário um perfeito contrôle químico e dosagem adequada da matéria prima, para garantir uma boa homogeneidade da mistura, aplicando-se, se pre ciso, correções na sua composição.

\subsection{Clinquerização}

Consiste no aquecimento controlado da mistura crua de vidamente dosada e homogeneizada, em fômo apropriado a tempe ratura de $1450-1500^{\circ} \mathrm{C}$.

A clinquerização constitui um conjunto de reações físico-químicas, que sofre a mistuxa crua (calcário e argila) tendo como produto final o clinquer. Estas reações conduzem a formação de quatro componentes essenciais: silicato tricálcico $\left(\mathrm{C}_{3} \mathrm{~S}\right), \quad$ silicato bicálcico $\left(\mathrm{C}_{2} \mathrm{~S}\right)$, aluminato tricálcico $\left(\mathrm{C}_{3} \mathrm{~A}\right)$ e ferroaluminato tetracálcico $\left(\mathrm{C}_{4} \mathrm{AF}\right)$, eventualmente acompanhados de cal livre ( $\left.\mathrm{CaO}\right)$, peri clásio (MgO), sulfatos, sulfetos, ferro metálico, etc.

As reações que ocorrem são de estado sólido. São fenômenos de difusão iônica entre os sólidos. Esta difusão é acelerada com o aparecimento de uma fase líquida (microlíquido), localizada na interface dos grãos e que começa a se formar a temperatura próxima de $1.300^{\circ} \mathrm{C}$. A velocidade de difusão e, consequentemente, a capaci dade de clinquerização são relacionados à quantidade e à, viscosidade da fase líquida.

Portanto à temperatura de clinquerização (acima de $1.300^{\circ} \mathrm{C}$ ) parte do material é constituído por uma fase líquida. A re lação de equilíbrio entre essa fase líquida e a fase sólida pode ser estudada com auxílio de diagramas de equilibrio, que representam um conjunto de investigações teóricomexperimentais, permitindo o conhecimento da existência de diferentes fases a diferentes tempera turas. O estudo dos diagramas de equilíbrio envolvendo $\mathrm{SiO}_{2}, \mathrm{CaO}$, $\mathrm{Al}_{2} \mathrm{O}_{3}, \mathrm{Fe}_{2} \mathrm{O}_{3}$ não consideram o efeito de soluções sólidas diluidas no sistema de fases, influência de voláteis, influência de fundentes, e a presença de impurezas, que provocam modificações nos sistemas e cujos efeitos na estabilidade e crescimento dos minerais, pouco se co. nhecem. 
2.5. Resfriamento

O clinquex saj do fôrno a uma temperatura aproximada de $1.200^{\circ} \mathrm{C}$ e sofre um tratamento, no resfriador industrial, para reduzir rapidamente a sua temperatura para $50-70^{\circ} \mathrm{C}$.

Diversos são os tipos de resfriadores existentes. $O$ mais utilizado consiste em um tubo cilíndrico giratório, ligeiramente inclinado, situado abaixo do fôrno, no qual o clinquer vai caindo para resfriar-se. O resfriador mais eficaz é do tipo grelha móvel, situado abaixo do fôrno, dotada de um movimento de vai e vem, que assegura o avanço do clinquer que cai. A grelha é atravessada por uma corrente de ar.

2.6. Adições finais e moagem do clinquer

O clinquer resfriado é transportado paxa a moagem final para atingir a finura conveniente, onde é também acrescido de uma certa quantidade de aditivos. O gipso normalmente utilizado para regular o tempo inicial "de pega" do cimento é limitado em até $5 \%$ em pêso.

2.7. Ensacamento

O cimento Portland, resultante da moagem do clinquer com o aditivo permitido, é transportado pneumáticamente para os silos de cimento à granel para a estocagem. Assegurada a sua qualidade, por ensaios físicos e químicos, o cimento é posteriormente colocado em sacos de $50 \mathrm{~kg}$.

\section{TERMOQUÍMICA DA FORMAÇAO DE CIMENTO PORTLAND}

No processo de formação de cimento, os calôres absor vidos e desenvolvidos, registram-ge às seguintes temperaturas (LEA $-1970)$. 
TABELA 1 - PRINCIPAIS REAÇOES NA FABRICAÇÃO C LINQUER

\begin{tabular}{|c|c|c|}
\hline T EMPERATURA & PROCESSO & REAÇAO \\
\hline até $100^{\circ} \mathrm{C}$ & Evaporação de água livre & endotérmica \\
\hline${ }_{\mathrm{ma}}^{500^{\circ} \mathrm{C} \text { e aci - }}$ & $\begin{array}{l}\text { Deshidroxilação dos mine- } \\
\text { rais argilosos }\end{array}$ & endotérmica \\
\hline \multirow{2}{*}{${ }_{\text {ma }}^{900^{\circ} \mathrm{C}}$ e aci- } & Recristalização de minerais & exotérmica \\
\hline & Decomposição do carbonato & endotérmica \\
\hline 900 a $1200^{\circ} \mathrm{C}$ & $\begin{array}{l}\text { Reação do CaO com os alu- } \\
\text { mino-silicatos }\end{array}$ & exotérmica \\
\hline 1200 a $1280^{\circ} \mathrm{C}$ & $\begin{array}{l}\text { Início de formação da fase } \\
\text { líquida }\end{array}$ & endotérmica \\
\hline acima de $1280^{\circ} \mathrm{C}$ & $\begin{array}{l}\text { Formação de fase líquida e } \\
\text { dos compostos de cimento } \\
\text { (clinquerização) }\end{array}$ & endotérmica \\
\hline
\end{tabular}


TABELA 2 - CALOR ABSORVIDO NA OBTENÇÃO DE $1 \mathrm{Kg}$ DE C LINQUER

\begin{tabular}{|l|c|}
\hline CALOR ABSORVIDO & kcal/kg de clinquer \\
\hline $\begin{array}{l}\text { Aquecimento da matéria prima de } \\
20^{\circ} \text { a } 450^{\circ} \mathrm{C}\end{array}$ & 170 \\
\hline Desidratação da argila a $450^{\circ} \mathrm{C}$ & 40 \\
\hline Aquecimento do material a $450^{\circ}$ a $900^{\circ} \mathrm{C}$ & 195 \\
\hline $\begin{array}{l}\text { Decomposição do material carbonático } \\
\text { Aquecimento do material carbonático }\end{array}$ & 475 \\
\hline decomposto de $900^{\circ}$ a $1400^{\circ} \mathrm{C}$ & 25 \\
\hline Calor de fusão & 1030 \\
\hline
\end{tabular}


TABELA 3 - CALOR LIBERADO NA FABRICAÇX̊ DE $1 \mathrm{Kg}$ DE C LINQUER

\begin{tabular}{|l|c|}
\hline \multicolumn{1}{|c|}{ CALOR DESENVOLVIDO } & kcal/kg de clinquer \\
\hline $\begin{array}{l}\text { Cristalização exotérmica das argìlas } \\
\text { desidratadas }\end{array}$ & 10 \\
\hline $\begin{array}{l}\text { Calor exotérmico da formação compo- } \\
\text { nentes do cimento }\end{array}$ & 100 \\
\hline $\begin{array}{l}\text { Resfriamento do clinquer de } 1400 \text { a } 20^{\circ} \mathrm{C} \\
\text { Resfriamento do CO } 2 \text { de } 900^{\circ} \text { a } 20^{\circ}\end{array}$ & 350 \\
\hline $\begin{array}{l}\text { Vapor de restriamento de } 450^{\circ} \text { a } \\
\text { 20 Co } \text { incluindo a condensação de } \\
\text { água }\end{array}$ & 120 \\
\hline \begin{tabular}{l} 
TOTAL \\
\hline
\end{tabular}
\end{tabular}


Podemos calcular a quantidade de calor requerido formar $1 \mathrm{~kg}$ de clinquer a partir de $1,55 \mathrm{~kg}$ de calcário e argila.

A oxdem relativa das quantidades teóricas de calor envol vido nos vários estágios de fabricação de cimento, para o cálculo da quantidade de calor necessário para formar $1 \mathrm{~kg}$ de clinquer s̃ão dadas pelas Tabelas 2 e 3 .

O balanço da soma do calor absorvido e desenvolvido, nos dá o calor teórico requerido de $420 \mathrm{kcal} / \mathrm{kg}$ de clinquer. Este dado teórico, segundo diferentes autores, varia de 400 a $430 \mathrm{kcal} / \mathrm{kg}$ de clinquer. No processo industrial, devido a dissipação de calor nas instalações industriais e ao sistema de fồno atilizado, o calor requerido varia de 985 a $2.100 \mathrm{kcal} / \mathrm{kg}$ de clinquer (MEYER - 1952). O processo por via "sêca" requer em média $1.200 \mathrm{ical} / \mathrm{kg}$ de clinquer e por via "úmida" oscila por volta de $1.600 \mathrm{kcal} / \mathrm{kg}$ de clinquer.

\section{COMPONENTES DO C LINQUER}

4. 1. Silicato Tricálcico $\left(\mathrm{C}_{3} \mathrm{~S}\right)$

$\mathrm{O}_{3} \mathrm{~S}$, abreviação de $\mathrm{Ca}_{3} \mathrm{SiO}_{5}$, é um mineral de clinquer de cimento Portland que se apresenta sob grande número de formas polimórficas. Existem 6 formas desde a temperatura de $1.100^{\circ} \mathrm{C}$, cujos pontos de transição são dados na Tabela 4 (GUINIER e REGOURD $-1969)$.

TABELA 4 - FASES POLIMOREICAS DO $\mathrm{C}_{3} \mathrm{~S}$

\begin{tabular}{|l|c|}
\hline FORMA CRISTALINA & TEMPERATURA DE TRANSIÇAO ${ }^{\circ} \mathrm{d}$ \\
\hline Romboédrica (R) & 1050 \\
\hline Monoclínica II $\left(\mathrm{M}_{\mathrm{II}}\right)$ & 990 \\
\hline Monoclínica I $\left(\mathrm{M}_{\mathrm{I}}\right)$ & 980 \\
\hline Triclínica III & 920 \\
\hline Triclínica II & 600 \\
\hline Triclínica I & \\
\hline
\end{tabular}


As diferentes formas de $\mathrm{C}_{3} \mathrm{~S}$ apresentam pouca variação estrutural. As transformações são do tipo "deslocativas", estando ern jogo diferenças de energias tão fracas que não modificam sensi velmente as ligações químicas, resultando que todas as formas polimórficas possuem reatividades comparáveis.

Elementos com Al, Fe, Mg, Na, K, Mn, Cr, Ti e F, podem substituix diadoquicamente o $\mathrm{Ca}$ e o Si, dentro de certos limites, no retículo do $\mathrm{C}_{3}$ s provocando desordens reticulares e permi tindo nas condições ambientais, a estabilidade de fases de alta tempe ratura. Provocam também mudanças nas suas propriedades e influem no crescimento cristalino.

LOCHER (1960) estudando a influência do $\mathrm{Mg}$ e $\mathrm{Al}$ no $\mathrm{C}_{3} \mathrm{~S}$, verificou que o $\mathrm{Mg}$, além de substituir o $\mathrm{Ca}$ no retículo do $\mathrm{C}_{3} \mathrm{~S}$, influia na sua estabilidade quando abaixo de $1.200^{\circ} \mathrm{C}$. Verificou que a solubilidade do $\mathrm{Mg}$ aumentava com a temperatura: a $1.420^{\circ} \mathrm{C}$ até $1,5 \%$ de $\mathrm{MgO}$ e a $1.500^{\circ} \mathrm{C}$ até $2,5 \%$ de $\mathrm{MgO}$ poderia ser incorpo rado no $\mathrm{C}_{3} \mathrm{~S}$. O Al pode estar presente até o limite de $0,8 \%$ de $\mathrm{Al}_{2} \mathrm{O}_{3}$, que corresponde a $2 \%$ de $\mathrm{C}_{3} \mathrm{~A}$. Em estudos por microssonda verificou-se que ${ } \mathrm{C}_{3} \mathrm{~S}$ apresenta em média $3 \%$ de óxidos menores (TERRIER et al - 1968 e 1969). MIDGLEY (1968) obteve os seguintes valores, por microssonda: $\mathrm{CaO} 70,6 \% ; \mathrm{SiO}_{2} 25,2 \% ; \quad \mathrm{K}_{2} \mathrm{O}$ $\begin{array}{ll}0,1 \% ; & \mathrm{Na}_{2} \mathrm{O} \quad 0,3 \% ; \quad \mathrm{MgO} \quad 0,9 \% ; \mathrm{Fe}_{2} \mathrm{O}_{3} \quad 1,4 \% ; \mathrm{Al}_{2} \mathrm{O}_{3} \quad 1,2 \% ; \mathrm{TiO}_{2} \\ 0,1 \% ; & \text { e } \mathrm{Mn}_{2} \mathrm{O}_{3} \quad 0,01 \% .\end{array}$ $0,1 \% ;$ e $\mathrm{Mn}_{2} \mathrm{O}_{3} \quad 0,01 \%$.
As diferentes formas polimórficas e suas soluções só lidas (variações de estrutura e de quimismo), comuns em clinquers comerciais, são chamadas, genericamente, de alitas, reservando-se - têrmo $\mathrm{C}_{3} \mathrm{~s}$ para o composto de composição definida $\left(\mathrm{Ca}_{3} \mathrm{SiO}_{5}\right)$.

De todos os componentes de clinquer a alita é a maior responsável (tem maior influência) no endurecimento do cimento.

\subsection{Silicato Bicálcico $\left(\mathrm{C}_{2} \mathrm{~S}\right)$}

O $\mathrm{C}_{2} \mathrm{~S}$, abreviação de $\mathrm{Ca}_{2} \mathrm{SiO}_{4}$, apresenta 5 formas polimórficas bem definidas, desde a temperatura ambiente até 1.550 . $-1.500^{\circ} \mathrm{C}$, apresentadas na tabela 5 (GUINIER e REGOURD - 1969). Ao contrário do $\mathrm{C}_{3} \mathrm{~S}, \circ \mathrm{C}_{2} \mathrm{~S}$ apresenta estruturas nitidamente diferentes, podendo-se portanto prever propxiedades hidráulicas dife-
rentes. 
TABELA 5 - FASES POLIMÓRFICAS DO $\mathrm{C}_{2} \mathrm{~S}$

\begin{tabular}{|c|c|}
\hline FORMAS & SISTEMA CRISTALINO \\
\hline$\alpha c_{2} s$ & Trigonal \\
\hline$\propto_{\mathrm{H}}^{\prime} \mathrm{C}_{2} \mathrm{~S}$ & Ortorrômbico \\
\hline$\alpha^{\prime} \mathrm{C}_{2} \mathrm{~S}$ & Ortorrômbico \\
\hline$\beta \mathrm{C}_{2} \mathrm{~S}$ & Monoclínico \\
\hline$\gamma \mathrm{C}_{2} \mathrm{~s}$ & Ortorxômbico \\
\hline
\end{tabular}

$O$ esquema da transformação do $\mathrm{C}_{2} \mathrm{~S}$, abaixo apresentado é devido a NIESEL e THORMANN (GUINIER e REGOURD - 1968).

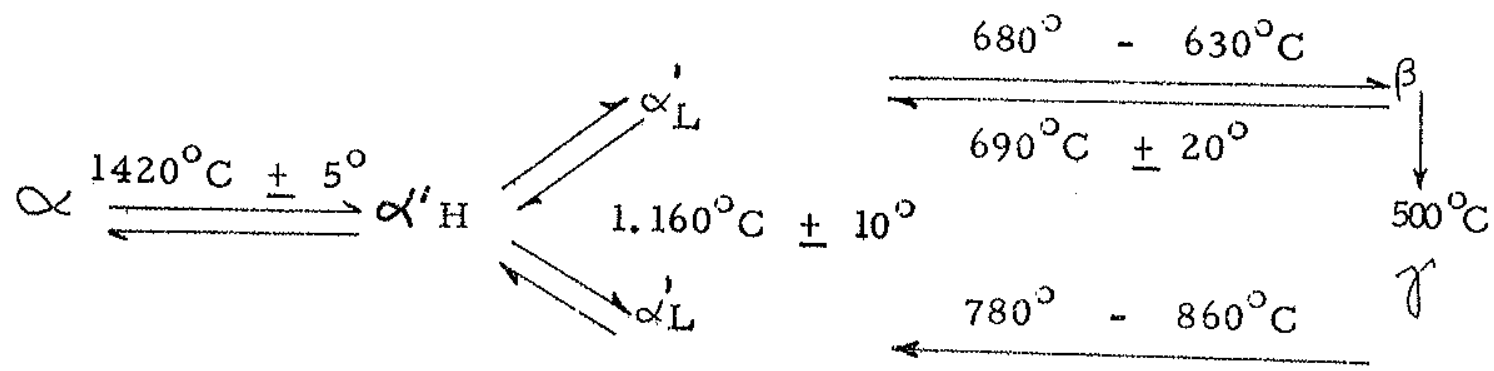

No estudo do polimorfismo do $\mathrm{C}_{2} \mathrm{~S}$, o problema mais importante é a txansformação de $\beta-\gamma$ e sua estabilização. Na forma $\beta \quad$ (larnita) o poliedro de coordenação do íon cálcio é irregulax e as ligações $\mathrm{Ca}-\mathrm{O}$ mais longas facilitam a hidratação. A for ma $\gamma$ é considerada inerte ou pouco hidráulica. Esta inércia se deve a coordenação simétrica do íon cálcio e a grande força de liga ६ão Camo, devida a baixa coordenação do cálcio. Segundo certas con dições termodinämicas, a forma $\beta$ pode passar para a forma $\gamma$, com variação do volume de $12 \%$ provocando a pulverização do clin quer.

As formas $\alpha=\alpha^{\prime}$, são pouco conhecidas mas é certo que apresentam certa hidraulicidade: METZGER (1953) em es tudos de microscopia de luz transmitida verificou que as inclusões 
arredondadas de $\mathrm{C}_{2} \mathrm{~S}$ ern $\mathrm{C}_{3}$ S eram de $\alpha^{\prime} \mathrm{C}_{2} \mathrm{~S}$ (bredigita).

Elementos como $\mathrm{Mg}$, Al, $\mathrm{Na}, \mathrm{Ba}, \mathrm{Ti}$ e outros, podem substituir o Ca e o Si, dentro de certos limites, no retículo do $\mathrm{C}_{2} \mathrm{~S}$, provocando desordens reticulares e estabilizando as diferentes for mas de $\mathrm{C}_{2} \mathrm{~S}$ nas condições ambientais. Provocam também variações nas suas propriedades.

O termo genérico belita, comum em clinquers comerciais, corresponde a um $\beta \mathrm{C}_{2}$ de retículo ligeiramente modificado pela adição de íons estranhos em forma de soluções sólidas.

Em estudos por microssonda verificou-se que o $\mathrm{C}_{2}$ s apre senta porcentagens de até $5 \%$ de óxidos menores (TERRIER et al 1968). FLETCHER (1968) obteve os seguintes valores em porcenta gem: 63,2 $\mathrm{CaO} ; 32,1 \quad \mathrm{SiO}_{2} ; 0,3 \quad \mathrm{~K}_{2} \mathrm{O} ; 0,3 \quad \mathrm{Na}_{2} \mathrm{O} ; 0,4 \mathrm{MgO}$; $0,8 \mathrm{Fe}_{2} \mathrm{O}_{3} ; 1,7 \quad \mathrm{Al}_{2} \mathrm{O}_{3} ; 0,3 \quad \mathrm{TiO}_{2} ; 0,03 \mathrm{MnO}_{2} ; 0,015 \quad \mathrm{P}_{2} \mathrm{O}_{5} ; \quad$ $0,010 \mathrm{SO}_{3}$.

A belita tem também contribuição importante na resistên cia aos esforços mecânicos do cimento.

\subsection{Fase Intersticial}

A fase intersticial do clinquer é originada da cristaliza §̧ão, durante o xesfriamento da fase líquida, e tem um importante papel no processo de clinquerização: quex físico químico, favore cendo e acelerando as reações de formação dos silicatos, quer físico-mecânico, regendo o mecanismo da granulação do clinquer e 'influindo na formação de anéis no fôrno de cimento. A fase intersticial é formada essencialmente por $\mathrm{C}_{3} \mathrm{~A}$ e $\mathrm{C}_{4} \mathrm{AF}$.

a) Aluminato Tricálcicico $\left(\mathrm{C}_{3} \mathrm{~A}\right)-\mathrm{OC}_{3} \mathrm{~A}$, abreviação de $\mathrm{Ca}_{3} \mathrm{Al}_{2} \mathrm{O}_{6}$ constitui a fase intersticial entre os cris tais de alita e belita. Cristaliza-se no sistema cúbico, mas a sua estrutura ainda não foi definida.Desempenha um importante papel na formação e desenvolvimento da fase líquida quando da clinquerização.

Em clinquers comerciais devido a presença de $\mathrm{Na}, \mathrm{K}$, $\mathrm{Mg}$, Ti, Si e Fe na sua estrutura, forma soluções só lidas, dentro de certos limites. TERRIER et al (1968). 
em estudos por microssonda verificaram que os álcalis tendem fixarse preferencialmente no $\mathrm{C}_{3} \mathrm{~A}$. FLETCHER (1969) em análises por microssonda de $\mathrm{C}_{3} \mathrm{~A}$ de clinquer industrial determinou os seguintes valores: $59 \% \mathrm{CaO} ; 29 \% \mathrm{Al}_{2} \mathrm{O}_{3} ; 6 \%$ de $\mathrm{Fe}_{2} \mathrm{O}_{3} ; 4 \%$ de $\mathrm{SiO}_{2} ; 1 \%$ de $\mathrm{K}_{2} \mathrm{O} ; 1 \%$ de $\mathrm{Na}_{2} \mathrm{O} ; \quad 0,5 \%$ de $\mathrm{MgO} ; \quad$ e $0,5 \%$ de $\mathrm{TiO}_{2} ; \quad 0,03 \% \quad \mathrm{Mn}_{2} \mathrm{O}_{3} ; \quad 0,15 \%$ de $\mathrm{P}_{2} \mathrm{O}_{5}$; e $0,10 \% \mathrm{SO}_{3}$.

A presença de álcalis, principalmente de $\mathrm{Na}$, pode, por resfriamento lento, formar um composto do tipo $\mathrm{Na}_{2} \mathrm{O} .8 \mathrm{CaO} .3 \mathrm{Al}_{2} \mathrm{O}_{3}$, provocando a mudança da sime txia cúbica para ortor rômbica (MOORE - 1966), apresentando-se ao microscópio sob hábito acicular.

Quando da hidratação, reage rapidamente com a água,con ferindo ao cimento a resistência inicial às solicitações mecânicas.

b) Ferro Aluminato Tetracálcico $\left(\mathrm{C}_{4} \mathrm{AF}\right)-\mathrm{OC}_{4} \mathrm{AF}$ ( ou brownmillerita), abreviação de $\mathrm{Ca}_{2} \mathrm{AlFeO}_{5}$ constitui, jun tamente com $\circ \mathrm{C}_{3} \mathrm{~A}$, a fase intersticial do clinquer. Cris taliza-se no sistema ortor rômbico.

CIRILLI e BRISI (1955) e NEWKIRK e THWAITE (1958) verificaram que o $\mathrm{C}_{4} \mathrm{AF}$ não é um composto definido,mas uma solução sólída de forma geral $2 \mathrm{Ca}$. $(\mathrm{Al}, \mathrm{Fe})_{2} \mathrm{O}_{3}$ re presentando um termo das soluções sólidas que varia de $\mathrm{C}_{2} \mathrm{~F}$ a $\mathrm{C}_{8} \mathrm{~A}_{3} \mathrm{~F}$.

GOURDIN (1967) estudando clinquers franceses verifi cou que a fase aluminoferrítica mais frequente apresen ta uma composição intermediária próxima de $\mathrm{C}_{4} \mathrm{AF}$.

A presença de elementos como Mg, Si, Na, K, Ti, Mn e outros na fase aluminoferrítica, forma soluções sóli das de composição complexa, não podendo ser expres-. sa por uma fórmula definida. VAN BEMST (1961) verificou em clinquers industriais que a composição da fase aluminoferritica depende mais do tratamento térmico, que da relação $\mathrm{Al}_{2} \mathrm{O}_{3} / \mathrm{Fe}_{2} \mathrm{O}_{3}$, em todos os casos onde o equilíbrio não é atingido. $\mathrm{OC}_{4} \mathrm{AF}$ apresenta valor hidráulico baixo e tem pequena 
participação na resistência aos esforços mecânicos do cimento. Sua propriedade principal é a resistência à corrosão química.

FLETCHER (1969), em análise por microssonda da fam se aluminoferrítica do clinquer industrial, determinou os seguintes valores: $57 \% \mathrm{CaO}, 20 \% \mathrm{Al}_{2} \mathrm{O}_{3}, \quad 13 \%$ $\mathrm{Fe}_{2} \mathrm{O}_{3}, \quad 6 \% \mathrm{SiO}_{2}, \quad 2 \% \mathrm{MgQ} \quad 2 \% \mathrm{TiO}_{2}, \quad 0,5 \% \mathrm{Na}_{2} \mathrm{O}$, $0,1 . \% \mathrm{~K}_{2} \mathrm{O}, \quad 0,03 \% \mathrm{Mn}_{2} \mathrm{O}_{3}, \quad 0,15 \% \mathrm{P}_{2} \mathrm{O}_{5}, \quad 0,10 \%$ $\mathrm{SO}_{3}$.

4.4. Outros componentes

Eventualmente podemos encontrar, por deficiência no processo de fabricação, ou pela presença de impitrezas nas maté rias primas: cal livre ( $\mathrm{CaO})$, periclásio $(\mathrm{MgO})$ e, secundariamen te, óxidos metálicos, sulfatos e sulfetos.

II W

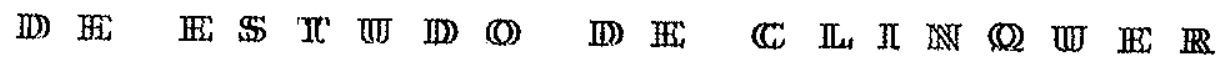

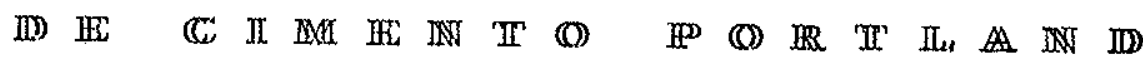

\section{1 - GENERALIDADES}

A. aplicação da microscopia óptica no estudo de clinquex de cimento Portland permite deduair desde a qualidade da matéria prima utjlizada para a sua fabricação até as condições do proces so tecnológico ao qual foi submetido, bem como prever as suas propriedades e seu comportamento como ligante hidráulico.

No escudo mictoscópio, observam-se os diferentes as pectos de escrutura, textura, porosidade, composição mineralógica, etc; que fornecem subsídios para o conbecimento da natureza e da granulometria das matérias primas, do grau de mistura entre elas, da temperatura e tempo de clinquerização, da quantidade de 
material fundente e das condições de resfriamento do clinquer. Através dos dados mineralógico e paragenéticos obsi dos podemse deduzir as causas dos desequilibxios que ocorreram na formação do clinquer, bem como as informaçōes importantes para a intexpretação da estória térmica e físicomquímica do p*ocesso de clinquerização, ao qual foram submetidas as matérias primas.

A seguir, será discutida a metodologia utilizada para se efetuar observações microscópicas para a deterininaçäo da compo sição mineralógica do clinquer. Os dados de análises químicas, utilim zados no cálculo da composição potencial. (BOGUE), completam o estudo microscópico, possibilitando um diagnose mais completa do clinquer.

2 - METODOLOGIA

2, 1. Amostragem

A amostragem do clinquex tem fundamental importân cia no estudo microscópico, quando se pretende que os resultados obtidos expressem realmente as condições de produção dentro de intervalo de tempo considerado.

Para presente estudo, que objetiva demonstrar a aplicabilidade da microscopia, os seguintes critéxios foram adotados:

a) considerando a representatividade da amostra envia da, normalmente de 2 a $5 \mathrm{~kg}$, seleciona-se $500 \mathrm{~g}$, por quarteamentos sucessivos.

b) escolhe-se ao azar, amostras compreendidas nos se guintes intexvalos granulométricos: maiores que 2 $\mathrm{cm}$, de 2 a $1 \mathrm{~cm}$, de 1 a $0,5 \mathrm{~cm}$ e menores que 0,5 crn。

c) das fxações granulométricas escolhidas separa-se metade para futuros estudos e a outra metade para es tudos microscópicos e análises químicas. 
2.2. Preparação da seção polida

No estudo por microscopia de luz refletida é fundamen tal a qualidade da superfície polida obtida. Uma preparação inade. quada da seção pode dificultar as observações microscópicas, além de falsear os resultados. Dois cuidados principais devem ser tomados:

- O clinquer sendo material poroso, as seções devem ser feitas à vácuo, de modo que os poros sejam preenchidos por poliester, material suporte, evitando assim a desagregação da estrutura e as dificulda des no polimento das seções.

- O material sendo hidraulicamente ativo, deve-se es colher um líquido inerte (querozene, alcool, etc) co mo meio dispexsante nas fases de pré-polimento e polimento das seções, assim como para lavagern e limpaza geral.

A preparação, propriamente dita, pode ser dividida nas seguintes etapas:

a) A.preparação da amostra que consiste em: corte do clinquer ao meio; nivelamento de uma das suas superfícies em lixa d'água; e, lavagem das seções.

b) A confeç̧̃o das seções de poliester que consta de: montagem das seções de clinquer em formas plásti cas sobre placas de vidro, devidamente untadas de "separol" para facilitax o deslocamento das seções de poliester; e, preenchimento à vácuo das formas plásticas contendo a seção de clinquer, com mistura de poliestex.

c) A fase de polimento das seções de poliester, devidamente endurecidas, consta das seguintes partes: des gaste das seções em lixa d'água no 150,300 e 400 (pré-polimento); e o polimento da seção nos 
diferentes estágios requeridos, na politriz "Buelher", utilizando-se de feltros com pasta de alumina, a velocidade de $250 \mathrm{rpm}$.

2.3. Ataque químico da seção polida

O estudo microscópico de uma seção polida de clin. quer requer ataque químico, para apresentar informações a respei to de seus constituintes minexalógicos, sem o que eles apresentam poderes refletores vizinhos, dificultando as suas caracterizações. Esse ataque deve ser feito dentro de condições técnicas cuidadosamente controladas, baseando-se nos dados das diferenças de velocidade de dissolução, de hidratação, etc. (Tabela 6)

\subsection{Análises modais}

No estudo quantitativo dos componentes mineralógicos do clinquer aplicou-se a metodologia para a determinação quanti tativa dos minexais de rocha, baseada na analogi a existente entre a expressão superficial dos minerais e as suas proporções volumé tricas.

Para a determinação quantitativa dos minerais de clinquer foi utilizado um microscópio metalográfico OLYMPUS e um contador de pontos CLAY ADAMS.

A contagem, por amostra de clinquer, foi deter minada em média para $4 \mathrm{grãos,} \mathrm{totalizando} 4.000$ pontos, sob aumento de $280 \mathrm{X}$ e espaçamento de contagem de 40 micras.

No cálculo de composição ponderal as seguintes densidades foram utilizadas: $\quad \mathrm{d}_{\mathrm{C}_{3} \mathrm{~S}}=3,13 ; \quad \mathrm{d}_{\mathrm{C}_{2} \mathrm{~S}}=3,28$;

$\mathrm{d}_{\mathrm{C}_{3} \mathrm{~A}}=3,0 ; \quad \mathrm{d}_{\mathrm{C}_{4} \mathrm{AF}}=3,77 ; \quad \mathrm{d}_{\mathrm{CaO}}=3,65 ; \quad \mathrm{d}_{\mathrm{MgO}}=$ $=3,22$. 
TABELA - 6 - REAGENTES UTILIZADOS NO ATAQUE DIFEREN CIAL DOS COMPONENTES DO CLINQUER

DO

\section{CIMENTO PORTLAND}

\begin{tabular}{|c|c|c|c|c|c|c|}
\hline \multirow[b]{2}{*}{ TEMPO DE ATAQUE } & \multicolumn{6}{|c|}{ COMPONENTES DO C LINQUER } \\
\hline & $\mathrm{C}_{3} \mathrm{~S}$ & $\mathrm{C}_{2} \mathrm{~S}$ & $\mathrm{C}_{3} \mathrm{~A}$ & $\mathrm{C}_{4} \mathrm{AF}$ & $\mathrm{CaO}$ & $\mathrm{MgO}$ \\
\hline $\begin{array}{l}\text { Água destilada, } 30 \\
60 \text { seg. }\end{array}$ & $t+t$ & ++ & + & & $+t+$ & \\
\hline $\begin{array}{l}1 \% \text { de } \mathrm{HCl} \text { em alcool } \\
\text { etílico, } 2 \mathrm{seg} .\end{array}$ & $t+$ & $t+$ & + & & $+t+$ & \\
\hline $\begin{array}{l}1 \% \text { de } \mathrm{HNO}_{3} \text { em alcool } \\
\text { etílico, } 2 \text { seg. }\end{array}$ & $+t$ & $+t$ & + & & $++t$ & \\
\hline $\begin{array}{l}10 \% \text { de HF em água, } \\
5-10 \text { seg. }\end{array}$ & & $+t+$ & + & & $++t$ & \\
\hline $\begin{array}{l}2 \% \text { de } \mathrm{NaOH} \text { em água, } \\
30 \mathrm{seg} .\end{array}$ & & & ++ & & $+t$ & \\
\hline $\begin{array}{l}\text { Reativo de Strelkow } \\
(0,25 \mathrm{ml} \text { de ac acé- } \\
\text { tico } 5 \mathrm{~N} \text { em } 100 \mathrm{~m} 1 \mathrm{de} \text { al } \\
\text { cool etílico), } 30-60 \mathrm{seg}\end{array}$ & azul & acast. & $\begin{array}{l}\text { cinza. } \\
\text { claro }\end{array}$ & & rôxo & \\
\hline $\begin{array}{l}1 \% \text { de Bórax em água } \\
3 \text { min. }\end{array}$ & $+t+$ & + & t & & $+t+$ & \\
\hline
\end{tabular}

NB - Adaptação das Tabelas de Terrier-Hornain (1967) e Paris (1968)

Legentla: +++ ataque intenso

++ - ataque médio

+ - ataque fraco 
2.5. Análises Químicas

A análise química dos clinqueres de cimento Portland foram determinadas no laboratório de Química da Associação Bra sileira de Cimento Portland, segundo a Norma Brasileira MB-11 da ABNT.

\section{3 - ESTUdOS MICROSCOPICOS}

3.1. Porosidade de clinquer

A porosidade de clinquer é a relação entre o volume de poros e o volume total ( $\mathrm{Vp} / \mathrm{Vt}$ ), cuja determinação é feita ao microscópio utilizando-se de um contador de pontos e uma plati na integradora.

A porosidade de um clinquer, segundo TERRIER e HORNAIN (1967) se deve a vários fatôres:

a) empacotamento inicial dos grãos, relacionado à granulometria do "cru".

b) temperatura e tempo de clinque rização.

c) quantidade e viscosidade da fase líquida.

Alguns grãos de clinqueres apresentam diferenças, de porosidade entre o seu núcleo e a periferia, que podem ser ori ginadas pelos seguintes fenômenos:

a) segregação dos constituintes mais fusíveis para as regiões mais externas do clinquer.

b) migração da fase líquida.

c) incorporação e reação de cinzas na superfície dos grãos.

d) aglomeração da poeira do reşfriador na superfície dos grãos. 
A alta porosidade de um clinquer, normalmente, indi w ca as seguintes causas:

a) una temperatura de clinquerização baixa, quando da presença de cristais de alita de pequeno desenvolvi mento (10 a 20 micja) e de zonas com indŕcios de reação incompleta (pouco "cozimento").

b) deficiência de elementos que facilitam a formação da fase líquida (fundentes: Al e Fe), quando os cris . tais de alita ap:esentam desenvolvimento normal (40 micra).

c) deficiencia na moagem da matéria prima, caxacteri zada principalmente pela presença de CaO livre (cal não combinada).

A. baixa porosidade, por outro lado indica:

a) uma temperatura de clinquerização altia, quando da presença de cristais de alita bem desenvolvidos (maior que 80 micxa) e de hábito alongado.

b) fase líquida abundante.

c) moagem elevada (finura alta)

E difícil estabelecer o fatox predominante de uma deter minada poxosidade, pois podem atuar simultâneamente diversos fatô $x$ es. No entanto é válido concluix que a temperatura de clinquexiza ". ção, a abundância da fase líquida e a granulometria do cru são os fatôres principais determinantes da porosidade.

No presente estudo, uma porosidade entre $20-30 \%$ se rá denominada de baixa; entre $30.40 \%$ de nomal e acima de $40 \%$ de alta. Esses têrmos envolvem um conceito estatístico-econômico sem prejuízo de qualidade. Em termos teóricos, clinquers muito po rosos indicam uma reação de clinguerização deficiente, pois presença de poros, portanto ausência de pontos de contacto, dificul ta as reações, provocando o aparecimento de zonas nuuito ricas em 
cálcio com alita e cal primária e zonas menos rica desse elemen to com belita.

3.2. Homogeneidade do clinguex

O aspecto homogêneo do clinquer, isto é, a regularida. de da distribuição dos cxistais de alita e belita se deve, principal mente, ao grau de mistura (homogeneidade do "cru") e de moagem do "cru". Portanto o aspecto não homogêneo do clinquer, caracteri zado pela distribuição dos cristais de alita, belita e também $\mathrm{CaO}$ li vxe primário em zonas, indica que durante o processo de clinqueriza ção, não havia uma boa distribuição dos elementos, provocando o aparecimento de zonas com excesso e deficiência de cálcio, respectivamente zonas de CaO livre primário e de belita.

a) Homogeneidade do "cru": é a regularidade da mistu $x$ a dos seus dois componentes principais: calcário e argila. Uma homogeneidade deficiente, durante a clinquerização, dá origem a concentrações irregula m res e poxtanto a formação de zonas, caracterizadas por cristais de CaO livre primáxio dispersos ou agru pados, que não puderam combinar-se por falta de sílica e zonas amplas de belita, com carência de fun dentes nas zonas adjacentes.

b) Grau de moagem do "cru" é a granulometria do "cru" necessário ao bom desenvolvimento das reações du w rante a clinquerização.

KRAMER (1957) vexificou o limite máximo de $100 \mathrm{mi}$ cra para calcários compactos e quartzo cristalizado. Grãos de cal. cários de diâmetro maiores que 100 micra, poderiam formar, no clinquer, zonas de CaO livre primário, com forma do grão de calcá. rio original.

Durante a clinquerização, o núcleo de grãos de calcário maior que 100 micra não reage devido à pequena mobilidade iônica do $C a$, que então permanece na forma de CaO livre. Os grãos 
de quartzo maiores que 100 micra seriam responsáveis por zonas de belita: como a sílica apresenta uma gxande tencěncia à migxaçã. ela dá origem a um poro rodeada por uma coroa de belita, na posi ção do grão original de quartzo (Foto 14). Por vezes encontrawse no nú. cleo de coroa belítica, zonas mais ricas em sílica, inclusive do quart zo, confirmando esse mecanismo.

LEHMANN e THORMANN (1964), em estudos experi mentais sobre a influência e granulometria do calcáreo nas reaçốs de clinquerização, observaram que quanto menor é o diämetro dos grãos, maior é o conteúdo e formaçăo dos cristais de alita e menor a porosidade do clinquer.

\subsection{Temperatura de clinquexização}

Uma temperatura adequada é um fator fundamental no desenvolvimento das reações. Permite também a formação de uma fase líquida que melhora o transporte dos íons influindo de maneira significativa na cinética da formação dos silicatos cálcicos, pxincipais.. responsáveis das propriedades ligantes do cimento.

As evidencias de uma temperatura adequada, no momen to da clinquerização, são dadas pelo idiomorfismo e tamariho dos cris w tais de alita, embora estes fatôres também sejam dependentes da composição do "cru".

Segundo TERRIER e HORNAIN (1967) os cristais de alita, a temperaturas superiores a $1.500^{\circ} \mathrm{C}$, apresentam-se com hâ w bitos prismáticos e alongado (acicular), maiores que $80 \mathrm{micra}$. A temperaturas inferiores a $1.450^{\circ} \mathrm{C}$, os cristais de alita idionórficos são pouco desenvolvidos e menores que 30 nicra, assim como o clinquer apresenta zonas pouco "cozidas", onde a reação foi incompleta. Em temperatura de clinquerização normal $\left(1.450^{\circ}-1.500^{\circ} \mathrm{C}\right)_{g}$ os cxis ... tais de alita são idomórficos e de dimensões entre 30 e 80 micra.

3.4. Tempo de clinguerização

A temperatura e o tempo de clinquerização são dois faw tốres interuligados, onde a dissociação nem sempre é fácil, pois 
ambos são os responsáveis pela formação e desenvolvimento dos cris tais de alita.

GIILE (1.955), em trabalhos experimentais, obteve um clinquer a baixa temperatura $\left(1.300^{\circ} \mathrm{C}\right)$, mantendo um tempo de clinquerização longo para que a reação fosse completa. O clinquer asm sim formado tem um aspecto muito poroso e os minerais são pouco desenvolvidos. Clinqueres formados a $1.450^{\circ} \mathrm{C}$ exigem apenas $5 \mathrm{mi}$ nutos para que a reação seja completa.

O tempo de clinquerização segundo PARIS et. al. (1968) é evidenciado pela forma e tamanho dos cristais. Cristais de alita maiores que $100 \mu$ caracterizam um tempo longo. Quando os cris tais são pouco desenvolvidos ( 10 a 20 micra) e existem zonas pouco "cozidas", pode-se diagnosticax um tempo curto.

3.5. Resfriamento do cilinquer

O resfriamento do clinquex é una das fases mais impor tantes da sua formação, pois dele depende a estabilidade, o idiomor fismo e a decomposição dos cristais de alita, a formação de belita se cundáxia, o conteúdo de cal livre secundária e a formação de peri clásio e do aluminato cálcico, Lembrar que estes dois últimos comm ponentes condicionam fenômenos de expansões no cimento.

Genericamente säo considerados dois tipos de resfria mentos (PARIS - 1968), que tem influência distinguiveis no estudo da composição e da textura minexalógica do clinquer: um que ocorre entre a zona de clinquexização e a boca de saída do fôn $\left.1.200^{\circ} \mathrm{C}\right)$, e outro que ocorre no resfriador industrial $\left(1.200^{\circ}\right.$ até 70 ou $50^{\circ} \mathrm{C}$ ).

O primeiro xesfriamento condiciona principalmente a estabilidade da alita e a formação da belita secundária digitada em amplas zonas.

O segundo resfriamento condiciona principalmente a cristalização da fase intersticial e do periclásio.

A alita, principal componente responsável pelo desen . volvimento da $x$ esistência aos esforços do cimento, forma-se às al tas temperaturas $\left(1.350^{\circ}-1.450^{\circ} \mathrm{C}\right)$ e segundo as observações de 
TROJER (1953), tornamse instável abaixo de $1.250^{\circ} \mathrm{C}$, decompondo - se em $\mathrm{C}_{2} \mathrm{~S}+\mathrm{CaO}$ livre secundário. E um mineral sensível às mu danças de composição e quimismo da fase líquida. Se o espaço de tempo decorrido desde o momento de sua formação até o final do res friamento for longo, a alita inicialmente formada estará em dese quilíbxio com a fase líquida, mais ácida, em temperaturas mais bai xas. Este desequilibrioterá como consequência o ataque da alita pela fase líquida, formando cristais de belita que se desenvolvem na superfície dos primeiros (Foto 21 ). Esse fenômeno é reconhecido em microscopia por cristais de alita de bordas corroídas, muitas ve zes profundamente penetrados pela fase intersticial, indicando que o primeixo resfriamento foi lento. Se o segundo resfriamento, também for lento, a alita se decomporá em $\mathrm{C}_{2} \mathrm{~S}+\mathrm{CaO}$ livre secundá ria.

WERMANN (1960) estudando o problema da decomposição da alita, verificou que este fenômeno ocorria somente em clinqueres ferrosos, com indicaçoses de aquecimento ema ambiente redu tor e resfriamento lento. Observou também que a presença de $\mathrm{MgO}$ điminuia a velocidade de decomposição da alita.

Em condições de resfriamento rápido, os cristais de alita são fraturados, com pouco indício de dissolução, constituin. do muitas vezes o mineral principal na poeira dos resfriadores (ALLEGRE et. a1. 1.960) devido as contraçöes térmicas que sofre esse mineral.

A. belita, mineral também importante no desenvolvimen to das resistências do cimento é bastante sensível as condições de resfriamento. As observaçöes microscópicas năo permitem distin guir as diferentes fases polimórficas da belita, mas o seu hábito e a presença ou não de geminação fornecem indicações sobre a taxa de resfriamento.

KRAMER (1957) vexificou que, no resfriamento rápido, a belita apresenta-se às vezes, fraturada e isenta de geminações. A medida que o resfriamento é mais lento, as geminações vão aparecen do e multiplicando-se em diversas direções (Foto 6). Em condições de resfriamento rnuito lento, a belita anteriormente arredondada, apresenta-se fortemente denticulada, até quase apresentar aspectos individualizados de segregação (Foto 21). Segundo ALEGRE (1957) - a cristalização da belita digitada tem origem a partir da dissolução. 
de alita pela fase líquida, durante o resfriamento. Este aspecto cor responderia a belita descrita por KRAMER (1957), como devido ao resfriamento lentis simo.

Excepecionalmente, quando do resfriamento extrema mente lento,pode ocorrer a palverização do clinquer pela transforma ६̧ão do $\quad \mathrm{BC}_{2} \mathrm{~S}$ em $\quad \mathrm{\gamma}_{2} \mathrm{~S}$ que é acompanhada por um aumento de volume 12\% (REGOURD - 1970).

Os constituintes da fase intersticial, os aluminatos e ferroaluminatos cálcicos, podem ser aplicados como termônetros (TROJER - 1953), para o conhecimento das condições de resfriamento no resfriador industrial (abaixo de $1.200^{\circ} \mathrm{C}$ ).

KRAMER (1957) estudando o aspecto da fase intersticial em relação ao resfriamento, registrou as seguintes observações:

a) resfriamento muito rápido, à água: a fạse intersticial praticamente não sofre ação segregativa e apresenta aspectos homogêneo, às vezes com alguns minúsculos germens dendríticos.

b) resfriamento rápido, por uma corrente de ax: a fase intersticial apresenta algumas fowmas de segregação, com a fase de aluminato apresentando aspecto irregu lar, distribuida caoticamente.

c) resfriamento lento, ao ar: a separação da fase aluminato e ferroaluminato é hem mais nítida, com cris tais de superfície bem delimitadas.

d) resfriamento muito lento, no fồno; a separação é mais nitida, percebendo-se facilmente os contônos geométricos dos cristais da fase intersticial e as fases silicáticas apresentam-se decompostas.

TERRIER e ALLEGRE (1957), estudando o comporta mento da fase intersticial de clinqueres comerciais, verificaram que a presença de cristais regulares bem desenvolvidos de aluminato cál cico é devida ao resfriamento lento (Foto 7). Fim casos de resfriamento rápido, o aluminato apresenta-se pequeno, mal formado e de. 
aspectos dendrítico. No resfriamento considerado normal o aluminato apresenta-se semi wcristalizado.

Na fase intersticial cristalizada pode aparecer cristais de forma acicular, devida a presença délcalis, que provoca es te hábito na fase aluminato, quando do resfriamento lento. Os álcalis $\left(\mathrm{K}_{2} \mathrm{O}+\mathrm{Na}_{2} \mathrm{O}\right)$ também influenciam na composição dos si licatos cálcicos e na formação de CaO livre secundáxia.

Em alguns clinqueres oxiginados de cálcareos magnesia nos ou dolomíticos pode ser verificado a presença de Mgo livre, em forma de periclásio, conforme as condições de resfriamento (KEIL 1954). O periclásio pode ser encontrado disseminado no clinquer ou agrupados em zonas. Quanto mais lento for o resfriamento, maior se rá o desenvolvimento dos cristais de periclásio.

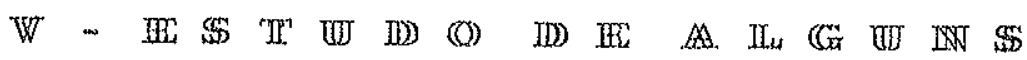

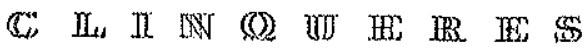

Aplicando-se os critérios mineralógicos descritos no capí tulo anterior, for am estudados 6 clinqueres de cimento Portland braw sileixos de procedências diversas, designados arbitrariamente de $A, B, C, D, E \in E$ 。

O processo de fabricaçäo é especificado, e quando possím vel, a matéria prima empregada é caracterizada.

Em quadros e tabelas săo apresentados diferentes aspec tos mineralógicos observados nos mesmos, sua porosidade, composiçôes modais, análises químicas, composições normativas, módulos de hidraulicidade, módulo de sílica e módulo de fundentes. 
1. OBSERVAÇÖES DOS ESTUDOS MICROSCOPICOS

TABELA 7 - OBSERVAÇÖES MICROSCÓPICAS DO CLINQULR A (FOTOS de 1 a 3 )

\begin{tabular}{|c|c|}
\hline COMPONENTE: & OBSERVAÇÖES \\
\hline Alita & $\begin{array}{l}\text { Cristais jdiomóricos pseudohexagonais, com } \\
\text { dimensões médias de } 40 \text { micra, sem evidências } \\
\text { de decomposição. Alguns cristais são alongados. } \\
\text { Apresentam inclusões de belita e CaO livre (râ } \\
\text { ros). Observammse zonas de segregação com } \\
\text { cristais variando de } 10 \text { a } 80 \text { nicra. }\end{array}$ \\
\hline Belita & $\begin{array}{l}\text { Cristais arredondados, de tamanho médio } \\
\text { micxa e frequentemente agrupados em zonas de } \\
400 \text { micra; alguns relacionados a grãos de quax } \\
\text { tzo. }\end{array}$ \\
\hline $\begin{array}{l}\text { Fase Intersti- } \\
\text { cial }\end{array}$ & $\begin{array}{l}\text { Semi "cristalizada, sem definj.cão dos alumina } \\
\text { tos cálcicos }\end{array}$ \\
\hline $\mathrm{CaO}$ & $\begin{array}{l}\text { Cristais axredondados de } 5 \text { a } 10 \text { micra, disper an } \\
\text { sos no clinquer }\end{array}$ \\
\hline $\mathrm{MgO}$ & $\begin{array}{l}\text { Cristais não bern formados, com dimensões de } \\
10 \text { micra e agxupados em zonas de até } 100 \text { micxa }\end{array}$ \\
\hline Fase Metálica & $\begin{array}{l}\text { Pouco frequente. Presente na fase intersticial, } \\
\text { nos cristais de alita e belita. }\end{array}$ \\
\hline
\end{tabular}

O clinquer A foi processado por via úmida e preparado a partir de calcáreos pré-cambrianos (Grupo Bambuí) e argilas quaternárias. 
TABELA. 8 - OBSERVAÇÖES MICROSCOPICAS DO CLINQUER B. (FOTOS de 4 a 8 )

\begin{tabular}{|c|c|}
\hline COMPONENTE & OBSER VAÇŌES \\
\hline Alita & $\begin{array}{l}\text { Cristais idiomórficos pseudohexagonais, di- } \\
\text { mensões médias de } 30-40 \text { micra. Inclu- } \\
\text { sões belíticas são comuns. Apresentam-se } \\
\text { frequentemente com bordas corroídas e de - } \\
\text { compostas. Ocorrem zonas alíticas. }\end{array}$ \\
\hline Belita & $\begin{array}{l}\text { Cristais arredondados de } 30 \text { a } 40 \text { micra, sen- } \\
\text { do comuns as formas digitadas. Alguns são } \\
\text { geminados e são frequentes as zonas belíticas, } \\
\text { algumas relacionadas a grãos de quaxtzo. }\end{array}$ \\
\hline $\begin{array}{l}\text { Fase Intersti } \\
\text { cial }\end{array}$ & $\begin{array}{l}\text { Cristalizada, com os aluminatos cálcicos de for } \\
\text { ma retangular e alguns aciculares. Os alumina } \\
\text { tos predominam sobre os fexroaluminatos cál } \\
\text { cos. }\end{array}$ \\
\hline $\mathrm{CaO}$ & $\begin{array}{l}\text { Arredondados e agrupados em zonas de até } \\
310 \text { micxa. }\end{array}$ \\
\hline $\mathrm{MgO}$ & $\begin{array}{l}\text { Cristais angulosos, com dimensões médias de } \\
12 \text { micra. Apresentam-se dispersos ou agrupa } \\
\text { dos em zonas de até } 120 \text { micra. }\end{array}$ \\
\hline Fase Metálica & $\begin{array}{l}\text { Raros, mas presentes envolvendo cristais de } \\
\text { alita ou inclusos em belita e na fase intersti - } \\
\text { cial. }\end{array}$ \\
\hline
\end{tabular}

$O$ clinquer $B$, foi processado por via úmida e prepaxado a partir de cálcareos pré-Cambrianos (Grupo são Roque) e rochas argilosas pa leozóicas e xistos e filitos alterados (Grupo São Roque). 
TABELA 9 - OBSERVAÇOES MICROSCOPICAS DO CLINQUER C (FOTOS de 9 a 12 )

\begin{tabular}{|c|c|}
\hline COMPONENTE & OBSERVAÇÖES \\
\hline Alita & $\begin{array}{l}\text { Cristais idiomórficos, pseudohexagonais, de } \\
\text { dimensões médias de } 50 \text { micxa. Alguns são } \\
\text { bem desenvolvidos (até } 140 \text { micra), outros } \\
\text { alongados. São frequentes as inclusões belŕ- } \\
\text { ticas e de CaO livre. Algumas evidências de } \\
\text { decomposição. São comuns cristais zonados } \\
\text { e zonas alíticas. }\end{array}$ \\
\hline Belita & $\begin{array}{l}\text { Cristais arredondados, dimensão média de } \\
30 \text { micra. São frequentes amplas zonas belí- } \\
\text { ticas. }\end{array}$ \\
\hline $\begin{array}{l}\text { Fase inters } \\
\text { ticial }\end{array}$ & $\begin{array}{l}\text { Mal cristalizada, sem definição dos (cris -- } \\
\text { tais) aluminatos cálcicos e com predominãn - } \\
\text { cia dếstes sobre os ferroaluminatos. }\end{array}$ \\
\hline $\mathrm{CaO}$ & $\begin{array}{l}\text { Cristais arredondados. Alguns estão inclusos } \\
\text { em alitas e outros estãodispersosno clinquer. }\end{array}$ \\
\hline $\mathrm{MgO}$ & Não observado \\
\hline $\begin{array}{l}\text { Fase metá- } \\
\text { lica }\end{array}$ & $\begin{array}{l}\text { Pouco frequente, presente na fase intersti - } \\
\text { cial, incluso em belita e preenchendo fratura } \\
\text { em um cristal de alita. }\end{array}$ \\
\hline
\end{tabular}

O clinquer $C$, foi processado por via úmida e preparado a partir de cálcareos pré-Cambrianos (Grupo Bambui) 
TABELA 10 - OBSERVAÇOES MICROSCÓPICAS DO CLINQUER (FOTOS de 13 a 17 ).

\begin{tabular}{|c|c|}
\hline COMPONENTE & OBSERVAÇOES \\
\hline Alita & $\begin{array}{l}\text { Cristais idiomórficos, pseudohexagonais de } \\
\text { dimensões médias de } 40 \text { a } 50 \text { micra.São fre - } \\
\text { quentes as inclusões de belita e decomposi } \\
\text { ção das bordas da alita. }\end{array}$ \\
\hline Belita & $\begin{array}{l}\text { Cristais arredondados, de dimensão média } \\
\text { de } 30 \text { micra com inácio de digitação. São frem } \\
\text { quentes as formas digitadas. Comumente agrü } \\
\text { pados em zonas amplas de até } 1000 \text { micra, } \\
\text { evidenciando origem relacionada a grãos de } \\
\text { quartzo. }\end{array}$ \\
\hline $\begin{array}{l}\text { Fase inters- } \\
\text { ticial }\end{array}$ & $\begin{array}{l}\text { Cristalizada, com cristais de aluminatos cál } \\
\text { cicos de contornos definidos. Em algumas } \\
\text { áreas aparecem cristais aciculares. }\end{array}$ \\
\hline $\mathrm{CaO}$ & $\begin{array}{l}\text { Cristais axredondados e agrupados em zonas } \\
\text { bem definidas de dimensões de até } 2.000 \mathrm{mi}- \\
\text { cra, algumas associadas a cristais de peri- } \\
\text { clásio. }\end{array}$ \\
\hline $\mathrm{MgO}$ & $\begin{array}{l}\text { Cristalizados em formas angulares, com di - } \\
\text { mensões de até } 16 \text { micra. Agrupados em zo - } \\
\text { nas e as sociados a CaO livre. }\end{array}$ \\
\hline $\begin{array}{l}\text { Fase me- } \\
\text { tálica }\end{array}$ & $\begin{array}{l}\text { Raros e quando presentes estão envolvendo } \\
\text { cristais de alita, ou inclusos em belita, ou } \\
\text { ainda na fase intersticial. }\end{array}$ \\
\hline
\end{tabular}

O clinquer $\mathrm{D}$ foi processado por via úmida e preparado a partix de calcáreos e filitos alterados do Grupo Açungui. 
TABELA - 11 - OBSERVAÇÖES MICROSCOPICAS DO CLINQUER E (FOTOS 18, 19 e 20).

\begin{tabular}{|c|c|}
\hline COMPONENTE & OBSERVAÇOOES \\
\hline Alita & $\begin{array}{l}\text { Cristais idiomórficos, pseudohexagonais, de } \\
\text { tamanho médio } 30 \text { micra, sendo alguns alonga } \\
\text { dos. Apresentam inclusōes de belita e CaO.De } \\
\text { composição incipiente dos cristais de alita. } \\
\text { Observam-se zonas de segregação. }\end{array}$ \\
\hline Belita & $\begin{array}{l}\text { Cristais arredondados, pouco digitados, de ta } \\
\text { manho médio } 30 \text { micra. Frequentemente agrü } \\
\text { pados em zonas amplas, com ou sem abundān- } \\
\text { cia da fase intersticial. Algumas zonas estão } \\
\text { relacionadas a grãos de quartzo. }\end{array}$ \\
\hline $\begin{array}{l}\text { Fase inters - } \\
\text { ticial }\end{array}$ & $\begin{array}{l}\text { Cristalizada, com cristais de aluminatos cál } \\
\text { cicos distintos e com formas definidas. }\end{array}$ \\
\hline $\mathrm{CaO}$ & $\begin{array}{l}\text { Arredondados e agrupados em zonas de } 180 \mu \\
\text { em média, algumas com até } 400 \text { micra }\end{array}$ \\
\hline $\mathrm{MgO}$ & Não observado \\
\hline $\begin{array}{l}\text { Fase } \\
\text { metálica }\end{array}$ & $\begin{array}{l}\text { Raros, inclusos na fase intersticial e na beli } \\
\text { ta, ou envolvendo cristais de alita. }\end{array}$ \\
\hline
\end{tabular}

O clinquer $E$, foi processado pox via seca e preparado a partix de calcáreos pré-Cambrianos. 
TABELA 12 - OBSERVAÇOES MICROSCOPICAS DO CLINQUER F (FOTOS 21 e 22).

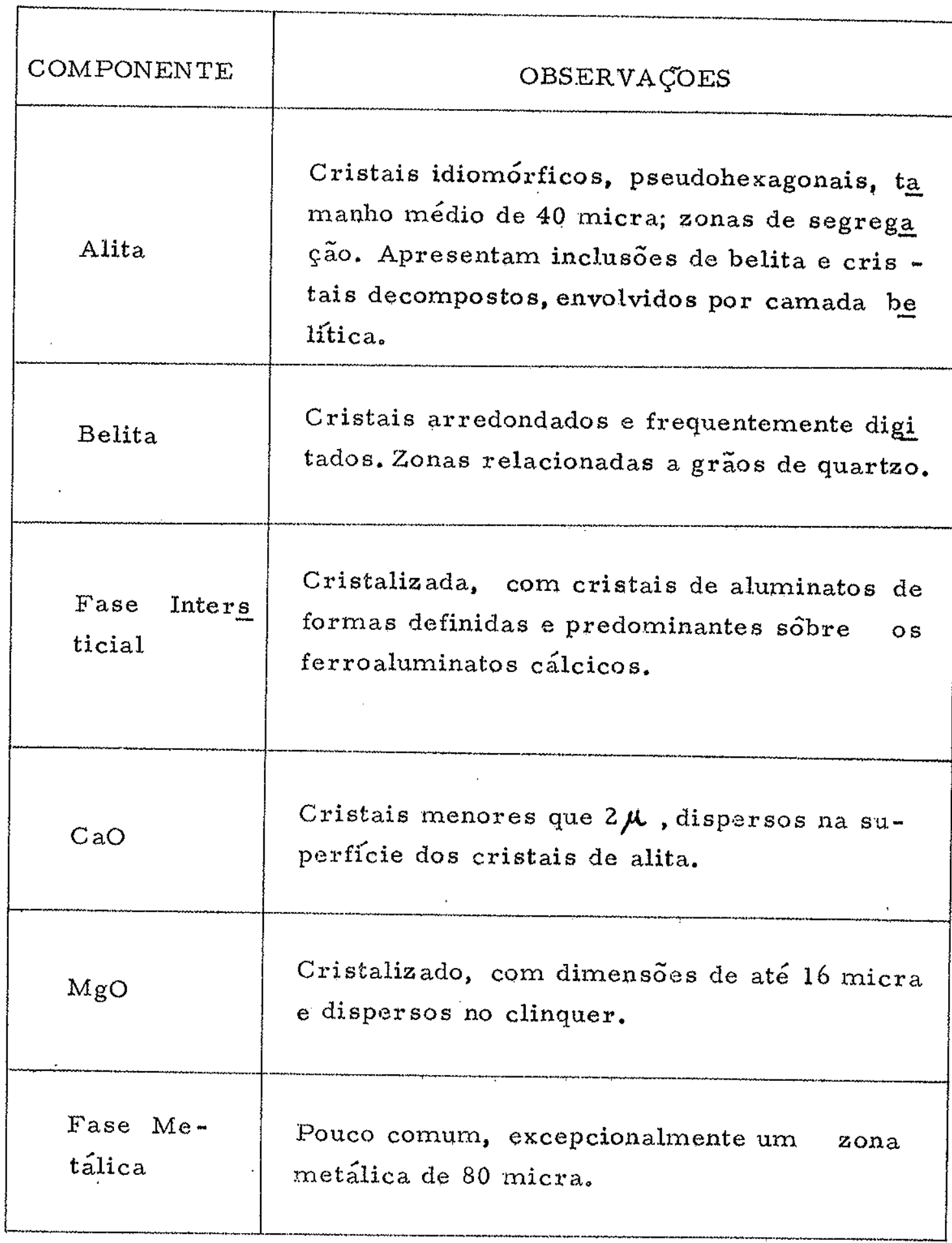

O clinquer Ji foi processado por via úmida e preparado a partir de calcáreos, xistos e filitos alterados do Grupo São Roque. 
2. POROSIDANE EM PORCENTAGEM

TABELA 13 - POROSIDADE DOS CLINQUERES

\begin{tabular}{|c|c|c|c|c|c|c|}
\hline $\begin{array}{c}\text { POROSI } \\
\text { DADE } \\
(\%)\end{array}$ & A & B & C & D & I & F \\
\cline { 2 - 6 } & 23,9 & 37,8 & 29,6 & 29,8 & 32,9 & 26,2 \\
\hline
\end{tabular}

3 - COMPOSIÇAO MODAL

TABELA 14 - COMPOSTÇAO MODAL (\% EM PESO)

\begin{tabular}{|c|c|c|c|c|c|c|}
\hline C LINQUER & $\mathrm{C}_{3} \mathrm{~S}$ & $\mathrm{C}_{2} \mathrm{~S}$ & $\mathrm{C}_{3} \mathrm{~A}$ & $\mathrm{C}_{4} \mathrm{AF}$ & $\begin{array}{c}\mathrm{CaO} \\
\text { livre }\end{array}$ & $\mathrm{MgO}$ \\
\hline $\mathrm{A}$ & 69,7 & 11,0 & 9,9 & 8,7 & 0,6 & 0,2 \\
\hline $\mathrm{B}$ & 55,7 & 18,0 & 10,6 & 8,5 & 1,7 & 5,5 \\
\hline $\mathrm{C}$ & 40,7 & 40,6 & 10,1 & 6,9 & 1,5 & 0,2 \\
\hline $\mathrm{D}$ & 54,3 & 26,0 & 7,1 & 9,5 & 2,6 & 0,5 \\
\hline $\mathrm{E}$ & 57,8 & 17,2 & 9,3 & 10,2 & 5,5 & - \\
\hline $\mathrm{F}$ & 60,2 & 20,9 & 3,0 & 10,6 & - & 5,3 \\
\hline
\end{tabular}


4 ANÁLISES QUÝMICAS

TABELA 15 - ANÁLISE QUYMICA DOS CLINQUERES EXPRESSA EM \% DOS ÓXIDOS CONSTITUINTES.

\begin{tabular}{|c|c|c|c|c|c|c|}
\hline 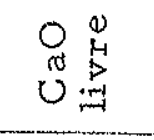 & $\begin{array}{l}m \\
0 \\
0\end{array}$ & $\stackrel{i}{N}$ & $\begin{array}{l}+1 \\
0\end{array}$ & $\tilde{N}$ & $\stackrel{\infty}{\sim}$ & $\begin{array}{l}\text { O } \\
0\end{array}$ \\
\hline 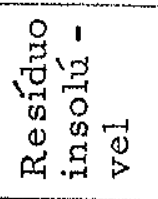 & $\begin{array}{l}\infty \\
0 \\
0\end{array}$ & $\stackrel{N}{N}$ & $\underset{n}{N}$ & $\begin{array}{l}\text { N } \\
0^{\prime \prime}\end{array}$ & $\stackrel{+1}{-1}$ & I \\
\hline $\mathrm{O}_{i}^{N}$ & $\stackrel{0}{N}$ & $\begin{array}{l}\infty \\
a \\
0\end{array}$ & $\stackrel{\sigma}{i}$ & $\begin{array}{c}\hat{0} \\
-1\end{array}$ & $\begin{array}{c}n-1 \\
n-1 \\
0\end{array}$ & ' \\
\hline 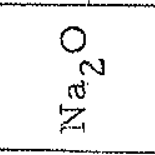 & $\begin{array}{l}\hat{0} \\
0\end{array}$ & $\begin{array}{l}m \\
4 \\
0\end{array}$ & $0_{n+1}^{n}$ & $\begin{array}{l}+4 \\
0^{+} \\
0\end{array}$ & ${ }^{n-1}$ & d \\
\hline $0^{m}$ & 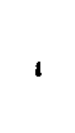 & m & $\begin{array}{l}n \\
0\end{array}$ & $-n$ & 1 & $\stackrel{m}{N}$ \\
\hline$\underset{\substack{0 \\
\sum_{i}}}{0}$ & $\begin{array}{l}m \\
\infty \\
i\end{array}$ & $\begin{array}{l}\text { a } \\
\text { in } \\
\text { in }\end{array}$ & $\begin{array}{l}1 \\
\infty \\
0\end{array}$ & $\stackrel{i}{i}$ & $\frac{a}{2}$ & $\begin{array}{l}m \\
b \\
10^{\circ}\end{array}$ \\
\hline $\begin{array}{c}0 \\
0 \\
0 \\
0 \\
0\end{array}$ & 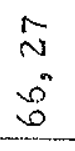 & $\begin{array}{l}n \\
n \\
0\end{array}$ & $\begin{array}{l}\infty \\
-1 \\
0 \\
0\end{array}$ & $\begin{array}{l}0 \\
m \\
j\end{array}$ & $\begin{array}{l}\infty \\
\infty+1 \\
\infty \\
\infty \\
0\end{array}$ & $\begin{array}{l}\infty \\
0 \\
n^{\prime \prime}\end{array}$ \\
\hline $0_{\substack{n \\
n_{n-1}^{m}}}^{m}$ & $\begin{array}{l}N \\
\infty \\
N\end{array}$ & 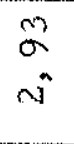 & $n$ & $\stackrel{0}{N}$ & $\begin{array}{l}m \\
w+1 \\
m^{n}\end{array}$ & $\begin{array}{l}\text { in } \\
m\end{array}$ \\
\hline$\overbrace{i}^{m}$ & $\begin{array}{l}0 \\
+1 \\
6\end{array}$ & $\stackrel{N}{\sigma}$ & $m$ & $\begin{array}{c}\hat{\sigma} \\
\text { மn }\end{array}$ & $\begin{array}{l}m \\
n \\
1 n^{n}\end{array}$ & $\stackrel{\infty}{m}$ \\
\hline $\begin{array}{cc}N \\
0 \\
0 \\
0\end{array}$ & $\begin{array}{l}\infty \\
N \\
N\end{array}$ & $\begin{array}{l}\infty \\
\infty \\
\infty\end{array}$ & $\begin{array}{l}m \\
0 \\
j\end{array}$ & $\begin{array}{l}N \\
N \\
n i\end{array}$ & 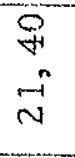 & $\begin{array}{l}6 \\
6 \\
-1 \\
-1\end{array}$ \\
\hline $\begin{array}{cc}0 \\
0 \\
0 \\
0 \\
4 \\
0 \\
0 \\
0 \\
0 \\
0\end{array}$ & $\begin{array}{c}n \\
0\end{array}$ & $\begin{array}{l}m \\
i n \\
0\end{array}$ & $\begin{array}{l}+\rightarrow \\
-1 \\
0\end{array}$ & 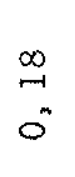 & $\begin{array}{l}9 \\
m \\
0^{n}\end{array}$ & ${ }_{m}^{m}$ \\
\hline 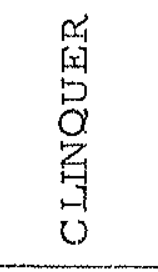 & $\varangle$ & 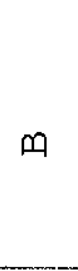 & $U$ & $\theta$ & $|x|$ & {$\left[x_{1}\right.$} \\
\hline
\end{tabular}


A semelhança do cálculo de normas de rocha (CIPW, por exemplo) pode-se calcular a composição potencial de un clinquer a partir de dados obtidos pelas análises químicas, ap?icando-se às fór mulas de Bogue (de uso comum tanto nás fábricas, como nos laboratórios de contrôle e pesquisa de cimento Portland).

As fórmulas de Bogue definem, a priori, o clinquer de cimento Portland como formado exclusivamente de silicato tricálcico $\left(C_{3} S\right)$, silicato bicálcio $\left(C_{2} S\right)$, aluminato tricálcico $\left(C_{3} A\right)$ e ferroalu minato tetracálcico $\left(\mathrm{C}_{4} \mathrm{~A} F\right)$, e admitem a existência de um equilíbrio entre as fases sólidas e líquida às altas temperaturas, levando tam bém em conta um resfriamento normal.

O método consiste em calcular a porcentagem de cada fa se mineralógica, a partir dos seus óxidos formadores, seguindo uma ordem imposta pela termodinâmica do processo e pela composição das fases:

$$
\mathrm{C}_{4} \mathrm{AF}, \quad \mathrm{C}_{3} \mathrm{~A}, \quad \mathrm{C}_{2} \mathrm{~S} \text { e } \mathrm{C}_{3} \mathrm{~S}
$$

As fórmulas de Bogue são:

$$
\begin{aligned}
& \mathrm{C}_{3} \mathrm{~S}: 4,07 \mathrm{CaO}-7,6 \mathrm{SiO}_{2}-6,72 \mathrm{Al}_{2} \mathrm{O}_{3}-1,43 \mathrm{Fe}_{2} \mathrm{O}_{3} \\
& \mathrm{C}_{2} \mathrm{~S}: 2,87 \mathrm{SiO}_{2}-0,754 \mathrm{C}_{3} \mathrm{~S} \\
& \mathrm{C}_{3} \mathrm{~A}: 2,65 \mathrm{Al}_{2} \mathrm{O}_{3}-1,69 \mathrm{Fe}_{2} \mathrm{O}_{3} \\
& \mathrm{C}_{4} \mathrm{AF}: 3,04 \mathrm{Fe}_{2} \mathrm{O}_{3}
\end{aligned}
$$

Os valores de $\mathrm{MgO}$ e CaO livre são considerados a partir dos resultados das análises químicas.

Como as condições de equilíbrio impostas por Bogue nem sempre são satisfeitas, pode-se efetuar correções como as sugexidas por LEA e PARKER (LEA, 1970).

Os resultados das análises químicas de clinqueres são apresentadas na tabela $n$ ? 15, átem V-4. As porcentagens dos óxidos, que entram na fórmula de Bogue, recalculados em $100 \%$ são apresen tados na tabela n! 16. A tabela n? 17 apresenta a composição potencial dos clinqueres de cimento Portland estudados. 
TABELA 16 - ANÄLISE QUYMICA CORRIGIDA EM 100\% PARA A FORMUIA DE BOGUE.

\begin{tabular}{|c|c|c|c|c|c|c|}
\hline $\mathrm{C}$ LINQUER & $\begin{array}{c}\mathrm{SiO}_{2} \\
\text { rotal }\end{array}$ & $\mathrm{Al}_{2} \mathrm{O}_{3}$ & $\mathrm{Fe}_{2} \mathrm{O}_{3}$ & $\mathrm{CaO}$ \\
$\mathrm{A}$ & 21,35 & 6,43 & 2,83 & 66,55 & 2,84 & 0,03 \\
\hline $\mathrm{B}$ & 20,28 & 6,40 & 2,99 & 64,61 & 5,71 & 1,27 \\
\hline $\mathrm{C}$ & 23,47 & 5,83 & 2,55 & 67,31 & 0,83 & 0,11 \\
\hline $\mathrm{D}$ & 22,88 & 5,79 & 2,78 & 66,28 & 2,26 & 1,31 \\
\hline $\mathrm{E}$ & 21,50 & 5,76 & 3,45 & 68,50 & 0,79 & 2,19 \\
\hline $\mathrm{F}$ & 22,04 & 4,46 & 3,56 & 64,20 & 5,73 & 0,20 \\
\hline
\end{tabular}


TABELA 17 - COMPOSIÇAO NORMATIVA (BOGUE) EM \%

\begin{tabular}{|c|c|c|c|r|r|c|}
\hline CLINQUER & $\mathrm{C}_{3} \mathrm{~S}$ & $\mathrm{C}_{2} \mathrm{~S}$ & $\mathrm{C}_{3} \mathrm{~A}$ & $\mathrm{C}_{4} \mathrm{AF}$ & $\begin{array}{r}\mathrm{CaO} \\
\text { livre }\end{array}$ & $\mathrm{MgO}$ \\
\hline $\mathrm{A}$ & 61,83 & 14,42 & 12,26 & 8,60 & 0,03 & 2,84 \\
\hline $\mathrm{B}$ & 58,36 & 13,45 & 11,91 & 9,09 & 1,27 & 5,71 \\
\hline $\mathrm{C}$ & 53,22 & 26,89 & 11,14 & 7,75 & 0,11 & 0,83 \\
\hline $\mathrm{D}$ & 49,56 & 27,58 & 10,64 & 8,45 & 1,31 & 2,26 \\
\hline $\mathrm{E}$ & 63,68 & 13,37 & 9,43 & 10,48 & 2,19 & 0,79 \\
\hline
\end{tabular}


6. MODULOS DE HIDRAULICIDADE, SILICA E FUNDENTES

TABELA 18 - MODULO DOS CLINQUERES

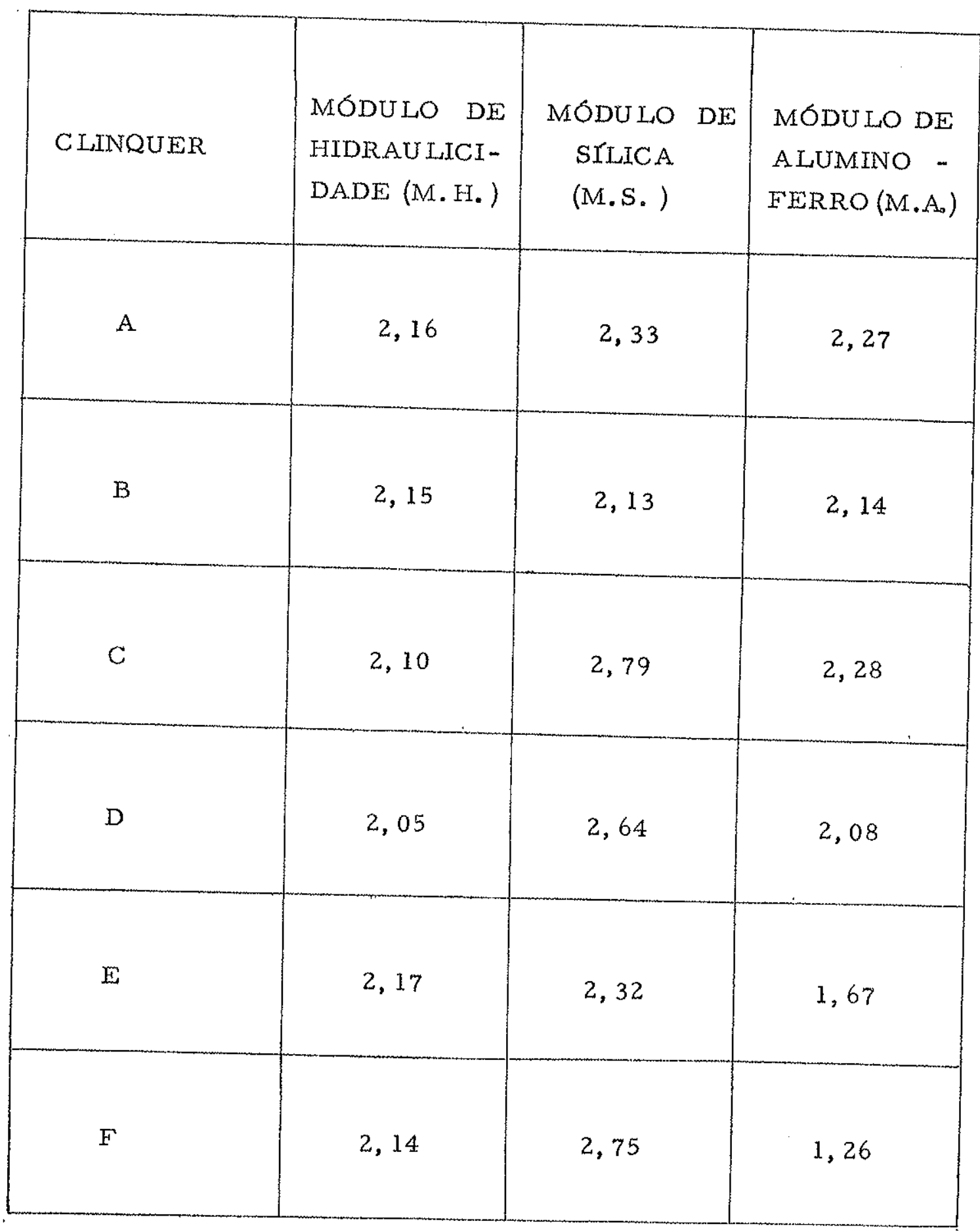


W II $-\mathbb{C} C O N$ IS II ID

W

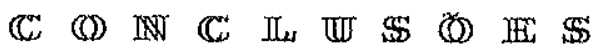

1 - CONSTDERAÇÖS SOBRE AS ANÁLISES MODAIS E NORMATIVAS

A composição modal (tabela 14) comparada com a composição normativa (tabela 17) dos clinquers estudados apresentam di vergências nos seus resultados, e permitem as seguintes observa çồes e discussões:

1. - A soma dos silicatos (alita + belita) obtida microsco picamente é maior que aquela obtida a partir da com posição normativa $\left(\mathrm{C}_{3} \mathrm{~S}+\mathrm{C}_{2} \mathrm{~S}\right)$, excepto para o clin quer E (tabela 19).

2. A fase intersticial (aluminato + ferroaluminato) deter minada microscopicamente é sempre menox que a calculada pelo método de BOGUE (tabela 21).

3. A porcentagem de CaO livre obtida por microscopia é maiox que a obtida a paxtir de análises químicas, excep to para a amostra F (tabela 22).

4. A porcentagem de $\mathrm{MgO}$ determinada microscols camen te é menor que a obtida a partir de análises đuími cas (tabela 24).

O exame microscópico da alita e belita não oferece dificul dades, pois os seus cristais são bem desenvolvidos e distintos, em bora em casos de resfriamento muito lento, a determinação quanti tativa de cristais pequenos de belita secundária possa apresertar al guma dificuldade. A diferença entre os totais de silicatos obticlos por microscopia e pelo cálculo normativo (tabela 19) é explicada em pax te pela formação de soluções sólidas e pela presença de álcalis e 
MgO (tabela 20) nos clinqueres estudados, que deslocam as condi ções de equilíbrio e também influem na velocidade de formação dos sílicatos.

TABELA 19 - SOMA DOS SILICATOS CÁLCICOS OBTIDA A PARTIR DO CÁLCULO NORMATIVOE MODAL.

\begin{tabular}{|c|c|c|}
\hline \multirow{2}{*}{ AMOSTRA } & \multicolumn{2}{|c|}{ SOMA DOS SILICATOS } \\
\cline { 2 - 3 } & BOGUE (\%) & MICROSCOPIA (\%) \\
\hline A & 76,2 & 80,7 \\
B & 71,8 & 73,7 \\
C & 78,1 & 81,3 \\
D & 77,1 & 80,3 \\
E & 77,0 & 75,0 \\
\hline F & 77,5 & 81,1 \\
\hline
\end{tabular}

O clinquer E apresentou resultados contrários a esta ten dência ao mesmo tempo que constatou -se que o seu CaO livre obti do quimicamence é bem inferiox ao obtido no microscópio, e conse quentemente pelo cálculo de Bogue, uma quantidade maior de silica tos cálcicos é registrada. A composição noxmativa xecalculada, con siderada a porcentagem de CaO livre obtida por microscopia (tabe la 23), levou a resultados convergentes com as amostras estudadas, isto é, a soma dos silicatos passou de 77,0 a 73,7. A influência đo CaO livre na formação dos silicatos será reforçada mais -adiante. 
TABELA 20 - PORCENTAGEM DE ÁLCALIS E MAGNESIA OBTIDA A PARTIR DE ANÁLISES QUÍMICAS

\begin{tabular}{|c|c|c|}
\hline AMOSTRA & ALCALIS (\%) & MAGNESIA $(\%)$ \\
\hline A. & 0,33 & 2,83 \\
B & 1,41 & 5,59 \\
C & 0,39 & 0,82 \\
D & 1,51 & 2,20 \\
E & 0,22 & 0,79 \\
F & nd & 5,63 \\
\hline
\end{tabular}

A fase intersticial, dependendo do resfriamento a que foi submetido o clinquer, oferece alguma djficuldade na diferenciação dós aluminatos e ferroaluminatos de cálcio por microscopia. Já foi dis cutido que quando o resfriamento é lento, a fase intersticial apresen.. ta se cristalizada, desenvolvida e diferenciada, e, à medida que o resfriamento torna-se mais rapido, a mesma tende a ser menos dife a renciada e desenvolvida, chegando até a formação de uma fasevítrea em casos extremos e dentro de condições particulares.

A natureza da fase intersticial é muito discutidarTAYLOR et al (1.964) admitem a formaçăo da fase vitrea em clinqueres comer ... ciais, variando de 2 a $12 \%$; por outro lado, outros trabalhos colo. cam em dúvida a possibilidade de formação de vidro ou fase vítrea nos mesmos (MIDGLEY, 1964); e KANTRO et al (1960) verifica .. ram que materiais designados de vidro ou fase vítrea são microcris . talinos, detectáveis à difração de raios X.

De qualquer forma, a natureza vitrea ou microcristalina da fase intersticial dificulta ao microscópio a distinçăo dos seus constituixtes, favorecendo as discrepâncias observadas nas porcenta gens de $\mathrm{C}_{3} \mathrm{~A}$ e $\mathrm{C}_{4} \mathrm{AF}$, calculados por microscopia e pelo método de Bogue (tabela 21).

A presença de $\mathrm{Al}_{2} \mathrm{O}_{3}$ e $\mathrm{Fe}_{2} \mathrm{O}_{3}$ nos sillicatos cálcicos, sob 
a forma de soluções sólidas, dentro de certos limites, tende a dimi nuir o conteúdo de $\mathrm{C}_{3} \mathrm{~A}$ e $\mathrm{C}_{4} \mathrm{AF}$, o que não é previsto pelos cálcu los de Bogue. Esse fenômeno pode explicar a maior quantidade de silicatos cálcicos determinados por microscopia, em relação a de terminado por Bogue.

TABELA 21 - SOMA DOS ALUMINATOS E FERROALUMINA TOS DE CAIMIO

\begin{tabular}{|c|c|c|}
\hline \multirow{2}{*}{ AMOSTRA } & FASE INTERSTICIAL $\left(\mathrm{C}_{3} \mathrm{~A}+\mathrm{C}_{4} \mathrm{AF}\right)$ \\
\cline { 2 - 3 } & BOGUE (\%) & MICROSCOPIA (\%) \\
\hline A & & \\
B & 20,8 & 18,6 \\
C & 21,0 & 19,1 \\
D & 18,8 & 17,0 \\
E & 19,0 & 16,6 \\
F & 19,9 & 19,5 \\
& 16,6 & 13,6 \\
\hline
\end{tabular}

Portanto as condições de resfriamento e a formação de soluções sólidas são os principais fatores que diminuem o conteú do de aluminatos e ferroaluminatos na fase intersticial, o que não é previsto nos cálculos da fórmula de Bogue.

O CaO livre primário, ou seja, o CaO proveniente da digestão incompleta de carbonatos é de fácil deteç̧ão ao microscópio (Fotos 16 e 18). A maior difículdade está na identificação de $\mathrm{CaO}$ livre secundário, produto da decomposição de alitas, que tem dimensões de alguns microns e apresentam-se disseminados nos cristais que the deram origem. Na tabela 22 säo apresentados os valores de $\mathrm{CaO}$ livre obtidos quimicamente e por microscopia.

Pelo estudo dada tabela, verificam-se discrepâncias sen síveis entre os valores das análises químicas e microscópicas. A 'dosagem de CaO livre é importante, porque pela fórmula de Bogue o 
TABELA 22 - PORCENTAGEM DE CaO LIVRE

\begin{tabular}{|c|c|c|}
\hline \multirow{2}{*}{ AMOSTRA } & CaO IIVRE \\
\cline { 2 - 3 } & BOGUE $(\%)$ & MICROSCOPIA (\%) \\
A & 0,03 & 0,6 \\
B & 1,27 & 1,7 \\
C & 0,11 & 1,5 \\
D & 1,31 & 2,6 \\
E & 2,19 & 5,5 \\
F & 0,20 & - \\
\hline
\end{tabular}

TABELA 23 - COMPOSIÇAO POTENCIAL RECALCULADA ( + CaO LIVRE CALCULADO QUIMICAMENTE; ++ : CaO LIVRE OBTIDO POR MICROSCOPIA).

\begin{tabular}{|c|c|c|c|c|}
\hline \multirow{2}{*}{ AMOSTRA. } & \multicolumn{3}{|c|}{ COMPOSTÇO POTENCIAL (BOGUE) } \\
\cline { 2 - 5 } & $\mathrm{C}_{3}{ }^{+}$ & $\mathrm{C}_{2} \mathrm{~S}^{+}$ & $\mathrm{C}_{3} \mathrm{~S}^{++}$ & $\mathrm{C}_{2} \mathrm{~S}^{++}$ \\
\hline $\mathrm{A}$ & & & & \\
$\mathrm{B}$ & 61,83 & 14,42 & 59,51 & 16,17 \\
$\mathrm{C}$ & 58,36 & 13,45 & 56,61 & 14,77 \\
D & 51,22 & 26,89 & 47,56 & 31,15 \\
E & 49,56 & 27,58 & 44,31 & 31,54 \\
F & 63,68 & 13,37 & 50,21 & 23,53 \\
& 57,91 & 19,59 & 58,73 & 18,97 \\
\hline
\end{tabular}


TABELA 24 - PORCENTAGEM DE MgO DETERMINADO POR ANÁLISE QUIMICA E POR MICROSCOPIA

\begin{tabular}{|c|c|c|}
\hline \multirow{2}{*}{ AMOSTRA } & \multicolumn{2}{|c|}{ MgQ } \\
\cline { 2 - 3 } A & BOGUE (\%) & MICROSCOPIA (\%) \\
\hline B & 2,84 & 0,2 \\
C & 5,71 & 5,5 \\
D & 0,83 & 0,2 \\
E & 2,26 & 0,5 \\
F & 0,79 & 5,3 \\
\hline
\end{tabular}


$\mathrm{CaO}$ utilizado no cálculo é o resultado da diferença entre o $\mathrm{CaO}$ total menos o CaO livre, determinados quimicamente. GOURDIN (1969) ve rificou que uma diferença de $1 \%$ em CaO leva a um êrro de 4 a $5 \%$ a mais em $\mathrm{C}_{3} \mathrm{~S}$ e 2 a $4 \%$ a menos em $\mathrm{C}_{2} \mathrm{~s}$, em valor absoluto.

Tomando-se como base os valores de $\mathrm{CaO}$ livre obtidos por microscopia, recalculoumse a composição dos silicatos cálcicos pela fórmula de Bogue. Estes valores comparados com os originais (tabela 23) mostram a influência das deficiências de dosagem de $\mathrm{CaO}$ livre, na estimação dos teores de silicatos (vide sobretudo amostra $E$ nas tabelas e Foto 18). O CaO livxe dosado quimicamente na amos tra $F$, é provavelmente de oxigem secundária, produto da decomposição de alita (Fotos 21 e 22 ).

Vexifica-se que a dosagem de CaO livre é importante porquanto ela modifica o total de silicatos cálcicos e as proporções de $\mathrm{C}_{3} \mathrm{~S}$ e $\mathrm{C}_{2} \mathrm{~S}$ (tabela 23), ao mesmo tempo que tenderia a aumentar as discrepâncias verificadas na tabela 19. As causas principais dessas discrepâncias residem na precariedade das análises químicas de $\mathrm{CaO}$ livre e na velocidade de resfriamento do clinquer. Este último fator permite a decomposição de alita em belita e CaO livre secundário, o qual fica disseminado na superfície dos cristais de alita, dificultando sua determinação ao microscópio.

O MgO, quando cristalizado em pexiclásio, é facilmente identicável ao microscópio, devido ao seu xelêvo e forma cristalina (Fotos 6 e 17). Entretanto, em condições de resfriamento rápido, o periclásio formado é pequeno, mal desenvolvido e parte dele encon .. tra-se dissolvido na fase intersticial.

As diferenças dos valores obtidos por microscopia e por análises químicas (tabela 24), também são devidas ao fato de que par te do MgO encontramse em soluções sólidas nos minexais de clinquer. e que a sua cristalização e desenvolvimento em periclásio depende das condições de resfriamento.

Conclue wse que a composição potencial de um clinquer, cal culada a partix da fómmula de Bogue, pode resultar diferente da sua composição real.

Os motivos principais e responsáveis por êsse fato são abaixo alinhados:

1. A fórmula de Bogue tem como ponto de partida o diagra ma de equilíbrio entre as fases constituintes do clinquer 
num processo de resfriamento lento a partir de $2.000^{\circ}$ C. Teoricamente prevê a composição mineralógica de clinqueres de cimento Portland dentro da vaxiação usual de temperatura de clinquerização. No processo industrial, as condições de equilíbrio são dificilmente atingidas, concorrendo para isso: a velocidade de aquecimento, o tempo de clinquexização, a velocidade de resfriamento, a pequena quantidade de fase líquida e a lentidão dos processos de reação de troca e difusão iônicas nas fases sólidas.

2. BOGUE pressupõe a formação dos minerais $\mathrm{C}_{3} \mathrm{~S}$, $\mathrm{C}_{2} \mathrm{~S}, \quad \mathrm{C}_{3} \mathrm{~A}$ e $\mathrm{C}_{4} \mathrm{~A} . \mathrm{F}$ puros, não considerando presença de elementos como $\mathrm{K}_{2} \mathrm{O}, \mathrm{Na}_{2} \mathrm{O}, \mathrm{MgO}, \mathrm{MnO}$, $\mathrm{SO}_{3}, \quad \mathrm{TiO}_{2}, \mathrm{P}_{2} \mathrm{O}_{5}$ e outros, que deslocam as condi cões de equilibrio e formam, dentro de certos limi tes, soluções sólidas.

3. As condições de resfriamento podem influir na com posição mineralógica, quer na proporção de $\mathrm{C}_{3} \mathrm{~S}$ for mado, quer na cristalização da fase intersticial, resultando valores divergentes com aquêles calculados pe la fórmula de BOGUE.

Apesar das considerações críticas formuladas acima, a fórmula de BOGUE tem importância e utilidade prática, pois per mite dar uma idéia da composição do clinquer para o contrôle e aplic ação do cimento, sem o emprêgo de instrumentais muito sofis ticados, utilizando somente técnicas convencionais da Química Ana lítica.

Estas últimas considerações são tanto mais valiosas quão mais cuidadosas forem os contrôles de finura e homogeneização do cru, o tempo e a temperatura de clinquexização, as condições de resfriamento, a ausência de teores altos de álcalis, e, evidentemen te, o rigor das análises químicas. 
2. CONSIDERACOES SOBRE A MATERIA PRIMA: SUA PREPARACAO, ESTORIA TERMICA E QUALIDADE DO CLINQUER EM FUNCAO DA MICROSCOPIA.

O exame microscópico dos clinqueres de cimento Portland es tudados, considerados os critérios mineralógicos discutidos no capítum lo IV permite conclusões quanto as suas condiçôes de formação, desen volvimento e qualidade.

2.1. Porosidade do clinque $\mathbf{x}$

As porosidades dos clinquexes estudados (tabela 13) classificadas na Tabela 25 , evidenciam que as condições de formação dos clinqueres estudados for am adequados

TABELA 25 - POROSIDADE DO CLINQUER

\begin{tabular}{|c|l|}
\hline CLINQUER & POROSIDADE \\
\hline A & BAIXA \\
B & NORMAL \\
C & BAIXA A NORMAI \\
D & BAIXA A NORMAL \\
$E$ & NORMAI \\
BAIXA \\
\hline
\end{tabular}

2.2. Homogeneidade do cinquer

A homogeneidade do clinquer está relacionada 'a homogenei dade do "cru" e/ou ao seu grau de moagem. A avaliação dos clinque res estudados (Tabela 26) permite as seguintes considerações:

1. No processo industrial a perfeita distribuição dos cristais de alita e belita, indicatriz de uma boa homogeneidade, não é comum.

As matérias primas apresentam na sua composição com ponentes de propriedades físicas e químicas diferentes 
TABELA 26 - HOMOGENEIDADE DO CLINQUER

\begin{tabular}{|c|c|c|}
\hline CLINQUER & $\begin{array}{l}\text { HOMOGENEIDADE } \\
\text { DO } \\
\text { CLINQUER }\end{array}$ & CAUSA PRINCIPAI \\
\hline A & homogêneo & $\begin{array}{l}\text { preparação adequada } \\
\text { da matéria prima }\end{array}$ \\
\hline$B$ & heterogêneo & $\begin{array}{l}\text { deficiẽncia na moa- } \\
\text { gem do cru }\end{array}$ \\
\hline C & heterogêneo & $\begin{array}{l}\text { deficiência na homo.. } \\
\text { geneização do cru }\end{array}$ \\
\hline $\mathrm{D}$ & heterogèneo & $\begin{array}{l}\text { deficiẽncia na moam } \\
\text { gem do cru }\end{array}$ \\
\hline $\mathrm{E}$ & heterogêneo & $\begin{array}{l}\text { deficiência na moa- } \\
\text { gem do cru }\end{array}$ \\
\hline$F$ & homogêneo & $\begin{array}{l}\text { preparação adequada } \\
\text { da matéria prima }\end{array}$ \\
\hline
\end{tabular}


que influem nos processos de preparação e homogeneiza ção da mistura crua. Os clinqueres A e F são considerados homogêneos, embora existam pequenas zonas relacio nadas a grãos de quartzo e a grãos de calcários dolomí ticos, que eventualmente presentes, quando da moa gem das frações argilosas ou carbonáticas, não atingi ram a finura suficiente por apresentarem propriedades diferentes das respectivas fxações. São desvios que em escala diminuta são viáveis num processo industrial.

2. Os clinqueres $B, D$, e $E$ apresentam deficiências na moagem do "cru" refletidas pela presença de amplas zonas belíticas (Fotos 4, 13 e 14) zonas de CaO livre (Fo tos 16 e 18) e zonas de periclásio (Fotos 8 e 17).

3. O clinquer $C$ apresenta deficiência na homogeneização do "cru", refletida pelas amplas zonas de belita (Fotos 9 e 1.0) e CaO livre disperso no clinquer (Foto 12).

2.3. Temperatura de clinquerização

Em nenhum dos clinqueres estudados verificoumse condições que indicam uma tempexatuxa de clinquerização inadequada. To dos apresentam cristais formados e desenvolvidos (Foto 1) que permi tem considerá-los como formados em condições normais (Tabela 27).

2.4. Tempo de clinquexizaçäo

O desenvolvimento dos cristais de alita nas amostras estuda das permite considerá-los, de um modo geral, como formados em con dições normais de tempo de clinquerização (Foto 1). Entretanto algumas amostxas como $B$ e $E$ tiveram uma passagem mais rápida pela zona de clinquerização, ao passo que os clinqueres $C$ e D tiveram uma passagem mais lenta que refletiu no tamanho dos cristais de ali ta. Comparar por exemplo as fotos no 5 e 11 e 19 com a de $n$ ? 15. 
TABELA 27 - TEMPERATURA E TEMPO DE C LINQUERIZAÇAO

\begin{tabular}{|c|c|c|}
\hline Clinquer & Temperatura de clinquerização & $\begin{array}{c}\text { Tempo } \\
\text { de } \\
\text { clinquerização }\end{array}$ \\
\hline A & normal-alta & normal \\
\hline B & normal & normal \\
\hline C & normal-alta & normal \\
\hline D & normal & normal \\
\hline E & normal-alta & normal \\
\hline F & normal & normal \\
\hline
\end{tabular}


2.5. Resfriamento do clinquex

O estudo microscópico ( $T$ abelas de 7 a 12) permite as se guintes conclusões quanto as condições de resfriamento (Tabela 28) dos clinqueres estudados.

TABELA 28 - RESFRIAMENTO DO CILINQUER

\begin{tabular}{|c|c|c|c|}
\hline Clinquer & 19 Resfriamento & $2 \%$ Resfriamento & $\begin{array}{l}\text { Obs. } \\
\text { Fotos }\end{array}$ \\
\hline A & normal & normal-rápido & 1 e 2 \\
\hline B & lento & lento & 5 e 6 \\
\hline C & normal & normal-rápido & - \\
\hline D & normal -lento & lento & - \\
\hline E & lento & lento & 20 \\
\hline
\end{tabular}

2.6. Outros

a) presença de álçalis: pox microscopia, só pode ser cons tatada quando o clinquer sofre resfriamento lento.' Os clinqueres B e D apresentam evidencias (cristais aciculares de aluminato cálcico) concordando com os dados de álcalis determinados químicamente (Tabela 15) (Fo to 7 ).

b) presença de fase metálica: embora não seja frequente nas amostras estudadas, todos os clinqueres apresen tam uma fase metálica (Fotos 3 e 22), cuja origem é dj.scutível. Eventualmente pode provir dos desgastes das bolas de moinho. 


\section{WIII $-\mathbb{E} O \mathbb{O N} \mathbb{C}$}

A microscopia constitue - se num excelente método paxa o estudo de clinqueres de cimento Portland, fornecendo, embora sujeito a algumas limitações, uma composição mineralógica mais próxi ma da verdadeira, compaxada com aquela obtida a partir de análises químicas (BOGUE). Além disso constitui o único meio de análise das texturas, estruturas o das relações íntimas entre as fases coexistentes, as melhores indicadoras da estória térmica dos clinqueres.

Não fora a necessidade de uma laboriosa preparaça à das amostras, de um técnico especializado e do tempo gasto no estudo das mesmas, seria sem dúvida um método adequado ao contrôle de qualidade de produção de cimento, em caráter rotineiro. Entretanto, isso não impede, que o mesmo seja recomendável como semirrotina, visando a obtenção de um maior número de dados, os quais poderão ser úteis, para a perfeita diagnose da qualidade e dos processos en volvidos na sua obtenção.

As comparações efetuadas entre a composição normativa (BOGUE) e a análise modal dos clinquexes estudados, representam um grande crédito ao método microscópico.

As pesquisas sobre as condições termodinâmicas de forma ção das fases mineralógicas constituintes dos clinqueres, tem forne cido informações quanto a influência de impurezas nos sistemas de equilibrio de formação dessas fases. Novos trabalhos experimentais em projeto e/ou andamento, considerando a ocorrência de elementos menores presentes nas matérias primas e verificando a influência dos mesmos nas condições de equilibrio das fases, são de relevan te importância e podem trazer como consequência a ampliação ( ou restrição) das especificações para matérias primas próprias à produção de cimento e modificações para caracterização de suas reservas, como também, adaptaçōes dos processos de produção, objetivando qualidade e rendimento.

A grande semelhança entre o processo de clinquerização e o de formação de certas rochas metamórficas permite a extrapo lação de fenômenos ocorridos na clinquexização para a explicação de fenômenos que ocorrem nos processos de metamoxfismo, principalmen te nos processos físico químicos de formação de silicatos cálcicos. 
WIIIII - $A$ G IR A D HA

Os melhores agradecimentos são dirigidos à Associação Brasileira de Cimento Portland, na pessoa de sea superintendente Prof. Dr. Francisco de Assis Basilio, pelo incentivo e entusiasmo transmitido ao autor, como também pela concessão de recursos necessários à execuçäo da pesquisa.

Ao Prof. Dr. José Vicente Valarelli, orientador dos traba thos, o reconhecimento do autor pelo apoio e dedicação que sempre the dispensou.

Agradecimentos especiais ao Prof. Antonio Gabriel Inglez pelas sugestões e críticas apresentadas na execução e redação dos trabalhos.

É necessário ressaltar a colaboração do Laboratório de Química da Associą̧ão Brasileir a de Cimento Portland, na pessoa do Eng. Antônio Kropf Soares, pelas análises químicas executadas, como também aos seus técnicos e estagiários que auxiliaram na fase inicial deste trabalho, a quem o axtor registra os seus agradeci mentos.

Agradecimentos são extensivos a Srta. Vera Lucja dà Costa pela datilografia do texto e ao Sr. Jajme A. Silva pelos trabalhos de impressão. 
1 - ALEGRE, R. et TERRIER, P. - La microscopie du clinker au Centre d'Etudes des Liants Hydraxliques. Revae des Materiaux de Construction, (501) : 165-180, jun. 1957.

2 - BASILIO, Francisco de Assis - Cimento Portland. São Paulo, A. B.C.P., 1972 .

3 - CIRILLI, V. et BRISI, C. - Influenza del modolo calcareo sulla composizione della fase serrica del clinker de portland. Industria Italiana del Cemento, 25 (1): 5, jan. 1955.

4 - A.LEGRE, R. et TERRIER, P. - Sur la formation de poussières dans les refroidisseurs à clinker. Revue des Materiaux de Construction, (536) : 109-112, mai 1960.

5 - FLETCHER, K. E. - The analysis of belite in portland cement clinker by means of an electron probe microanalyser. Magazine of Concrete Reseaxch, 20(64):167-170, sep. 1968.

$6-$ - The composition of the tricalcium aluminate and ferrite phases in portland cement determined by the use of an electron-probe microanalyser. Magazine of Concrete Research, 21 (66) : 3-14, mar. 1959.

7 - GILLE, F. - Zur mikroskopse des Zements. Zement Kalk Gips, $8(4): 128-138$, apr. 1955.

8 - GOURDIN, P. - Composition minéralogique et propriétés des clinkers portland. Revue des Materiaux de Construction, (650) : 354-362, nov. 1969; (651) : 411-420, deq. 1969. 
9 - GUINIER, A. and REGOURD, M. - Structure of portland cement minerals. In : Proc. V International Symposium of the Chemistry of Cement, Tokio, v. 1, p. 1-43, 1968.

10 - KRAMER, H. - Klinkerungleichgewitchte und ihre unrsachen. Zement-Kalk-Gips, 10(8): 305-314, ago. 1957.

11 - KEIL, F. - Uber die Arbeiten des Forschungsinstitutes der Zementindustrie. Zement-Kalk-Gips, 7(9): 343-348, sep. 1954.

12 - LEA, F.M. - The chemistry of cement and concrete. 3 rd.ed. Glasgow, Ed. Arnold Pub., 1970.

13 - LEHMANN, H. y THORMANN, P. - Sobre la influencia del tamaño de granos de la caliza en la formación de los minerales del clinker. Materiales de Construccion Ultimos Avances, (115) : 5-18, jul/set. 1964.

14 - LOCHER, F.W. - Solid solution of alumina and magnesia in tricalcium silicate. In : Pros. IV International Sym posium of the Chemistry of Cement, Washington, v. 1 , p. $99-106,1960$.

15 - METZGER, A. - Uber das Vorkommen voa Bredigit $\left(\chi^{\prime}-\mathrm{Ca}_{2} \mathrm{SiO}_{4}\right)$ in Portland zementklinkera. Zement Kalk-Gips, 6(8): 269-270, ag. 1953.

16 - MEYER, K. and WENDEBORN, H. - Discussion of the paper Thermodynamics of the cement kiln, by $H_{0}$ Gygi. In : Proc, III International Symposium of the Chemistry of Cement, London, p. $782-787,1932$.

17 - MIDGLEY, H. G. - The composition of alite (tricalcium sili cate) in a portland cement clinker. Magazine of Concrete Research, 20(62): 41-44, max. 1968. 
18 - MOORE, A. E. - Tricalcium aluminate and related phases in portland cement. Magazine of Concrete Research, 18(55): 59-54, jun。 1966.

19 - NEWKIRK, T. F. and THWAITE, R.D. - Pseudoternary system calcium oxide monocalcium aluminate $\left(\mathrm{CaO} \mathrm{Al}_{2} \mathrm{O}_{3}\right)$ dicalcium ferrite $\left(2 \mathrm{CaO} \mathrm{Fe}_{2} \mathrm{O}_{3}\right)$. Journal of Research of the National Bureau of Standards, 61(4): 233-245, oct. 1958.

20 - REGOURD, M. - Cristallographie des constituantes du clinker de ciment portland. Bulletin de Liaison des Laboratoires Routiers, (Special 0): 58-73, jun. 1970.

21 - PARIS, J. M. F. - Microscopia del clinker de cemento port land: manuales y normas. Madrid, Instituto Eduardo Torroja, 1968.

22 - SCHAWTZ, 3. - Contribution a la phase aluminoferritique des clinkers de ciment portland. Revue des Materiaux de Construction (669/070): 159-172, jun./jul. 1971 .

23 - TAYLOR, H. F. W. - The chemistry of cements. London, Academic Press, 2v. 1964.

24 - TERRIER, P. et HORNAIN, H. - Sur l'application des méthods minéralogiques à l'industries des liantes hydrauliques. Revue des Materiaux de Construction, (618): $79-96 ;(619)$ : 123-140; (620): $177-187,1967$.

25 et - Sur la composition de l'aluminate tricalcique. Revue des Materiaux de Construction, (666): $60-69$, mai。 1971 .

26 et SOCROUN, G。 - Sur la composition des alites. Revue des Materiaux de Construction, (640): 14, jan. 1969. 
27 et et - Quelques applications de l'analyses par microsonde életronique à l'étude des minéraux du clinquer. Revue des Materiaux de Construction, (690): $109-115, \max .1968$.

28 - TROJER, F. - Schlusse aus mikroskopishen unter suchungen and Portland zement klinkern. Zement-Kalk-Gips, 6(9): $312-318$, set. 1953 .

29 - VAN BEMS'T, A. - Contribution à l'étude de l'evolution des réactions s'opérant entre les constituants des pâtes à cement Portland au cours de leur cuisson. Silicates Industriels, 26(6): $290-296,1961$.

30 - WOERMANN, E. - Decomposition of alite in technical portland cement clinker. In: Proc. IV International Symposium of the Chemistry of Cement, Washington, 1960, v. 1, p. 119 129. 
W - W

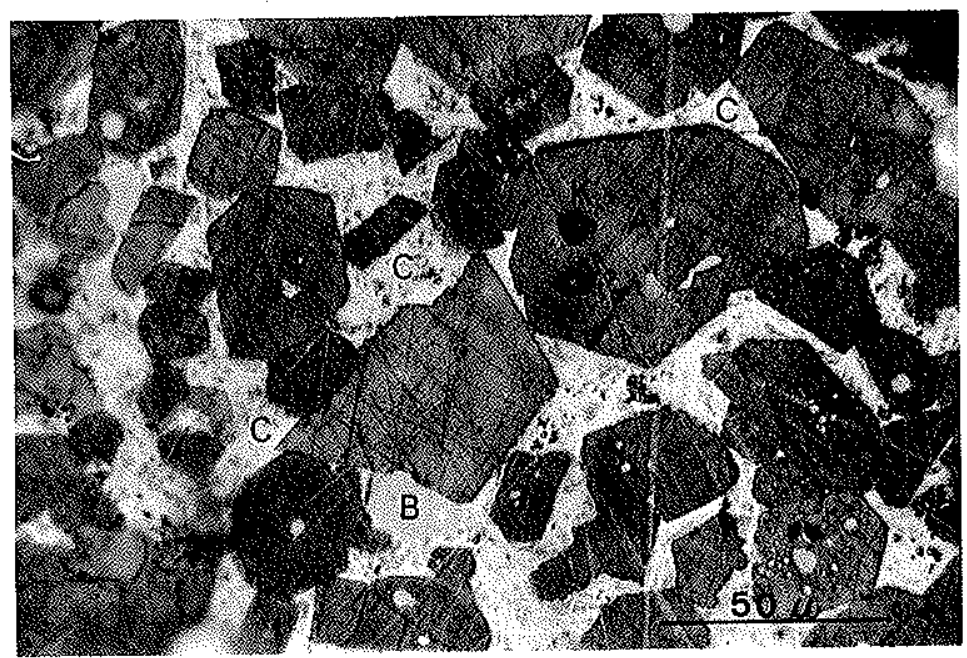

Foto 1 - Clinquer A - ataque: bôrax + NaOH (280X)

Cristais idiomórficos de alita (A), alguns com inclusões de CaO livre (K) e belita

(B); cristajs axredondados de belita $(B)$ e fase intersticial (C) semi-cristalizada, sem de finição dos aluminatos.

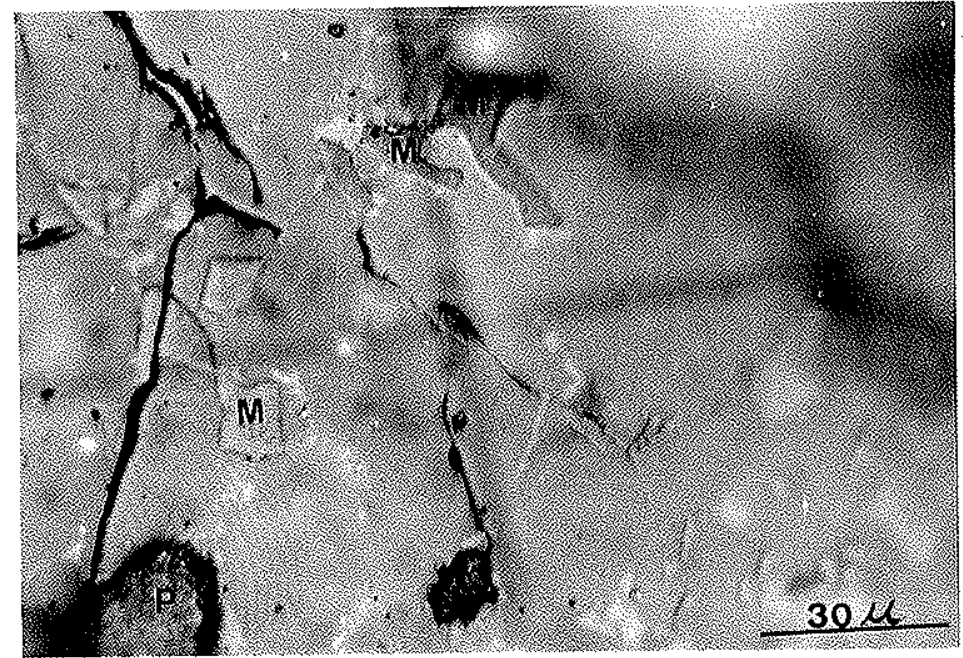

Foto 2-Clinquer A - sem ataque - (400X)

Cristais de periclásio (M) não bem formados e poros (P). O ressante é conscituido de silicatos e fase intersicicial não diferenciada. 


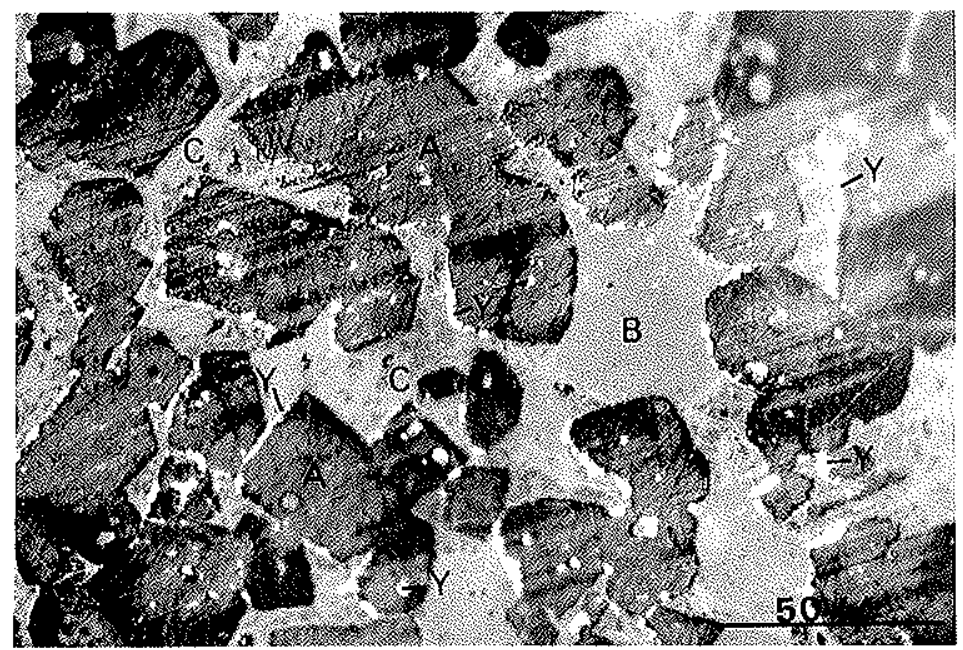

Foto 3 - Clinquer A - ataque: borax + NaOH - (280X) Aspecto da fase metálica (Y) presente nos componentes do clinquer. Cristais de ali ta (A) e belita (B) bem formados indicando temperatura e tempo de clinquerização adequados.

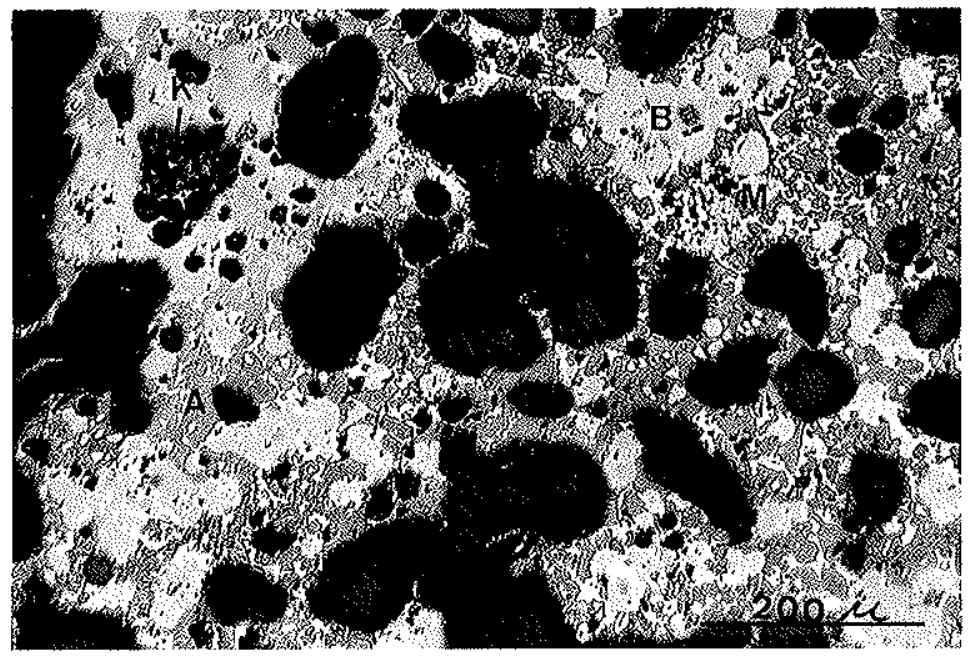

Foto 4 - Clinquex $\mathrm{B}$.. ataque: bórax $+\mathrm{N}_{2} \mathrm{O}$ (70X) Aspecto geral da porosidade do clinquer e das zonas de CaO livre (K), de periclásio $(\mathrm{M})$, de belita (B) e de allita (A) indicando deficiência na moagem do cru. 

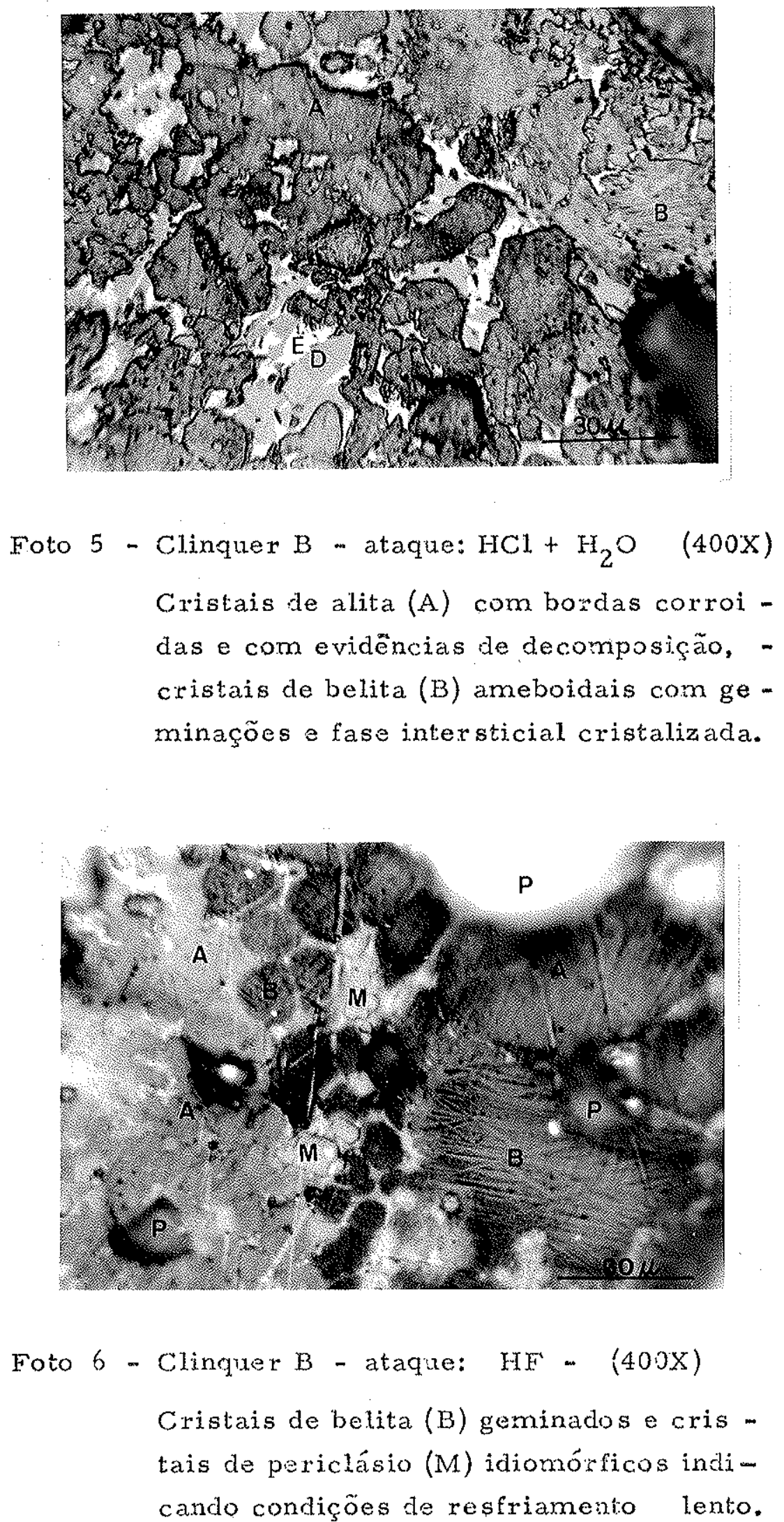


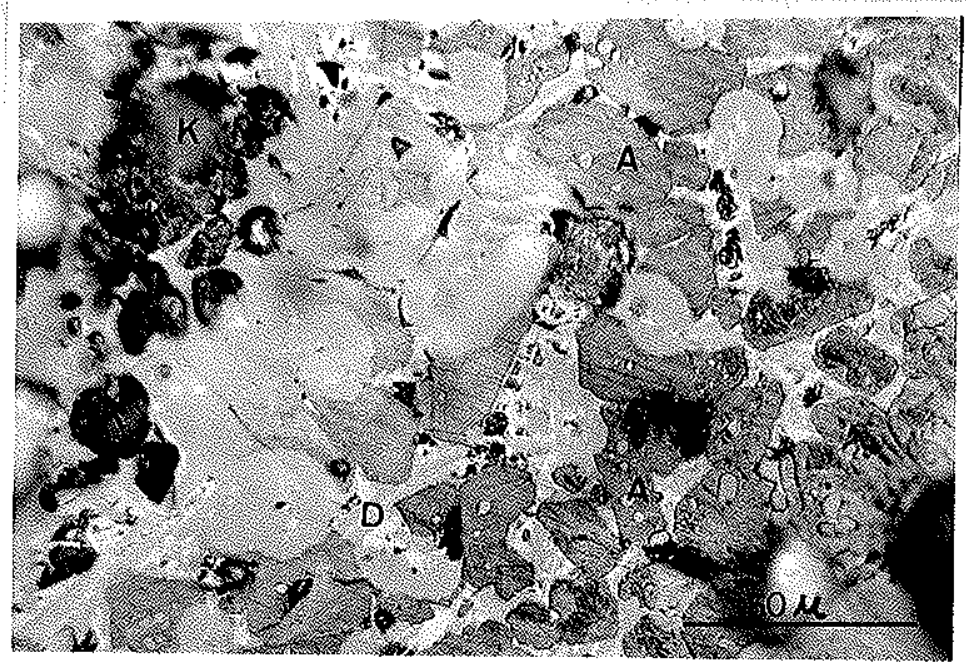

Foto 7 - Clinquex $B$ a ataque: Bórax - (280X) Zona de CaO livre (K), cristais decompos tos de alita (A) e fase intersticial cristali zada com cristais alongados de alumina tos cálcicos (D) indicando ação de álcalis.

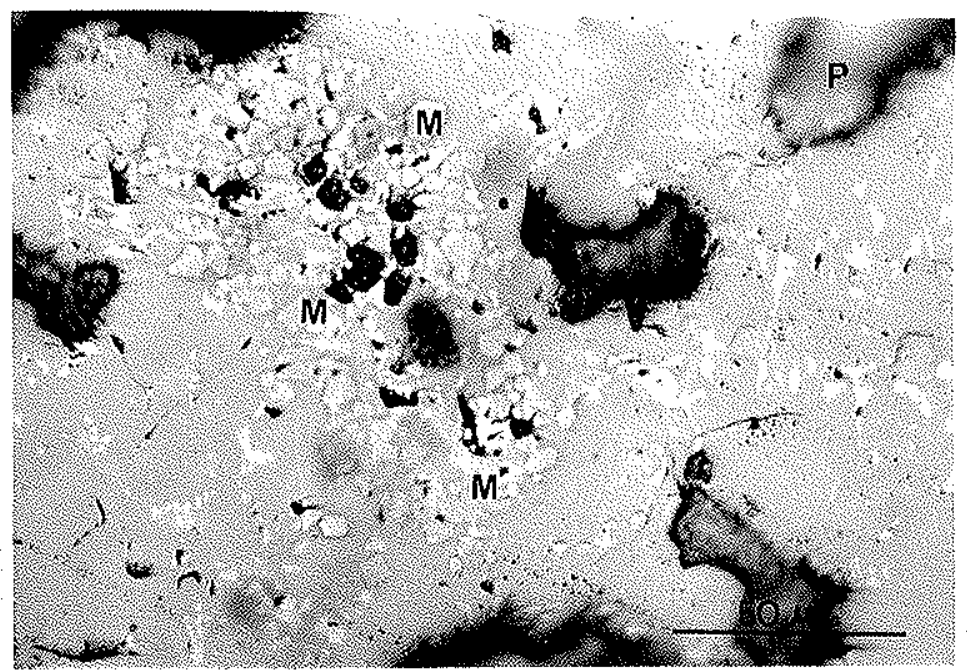

Foto 8 - Clinquex B - sem ataque - (280X)

Zona de periclásio (M) indicando deficiências na moagem do cru. 


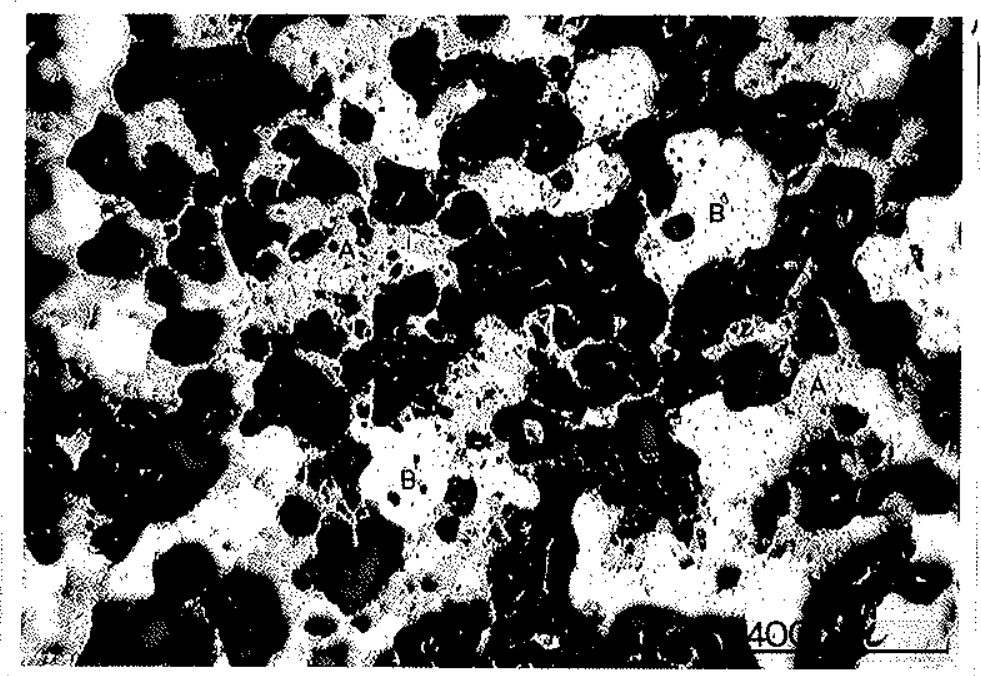

Foto 9 - Clinquer $\mathrm{C}$ - ataque: $\mathrm{H}_{2} \mathrm{O}$ + reat. Strelkow (28X)

Clinquer heterogêneo com amptas zonas de alita (A) e de belita (B).

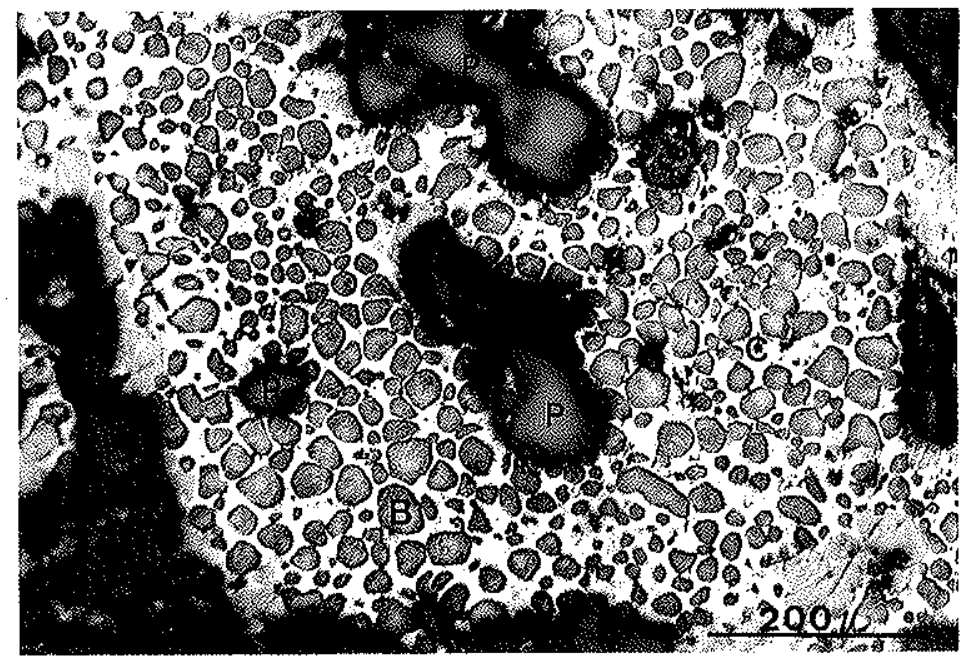

Foto10 - Clinquer C - ataque: HF m (70X)

Ampla zona belítica (B) com cristais arredondados indicando deficiências na homogei zação da matéria prima. 


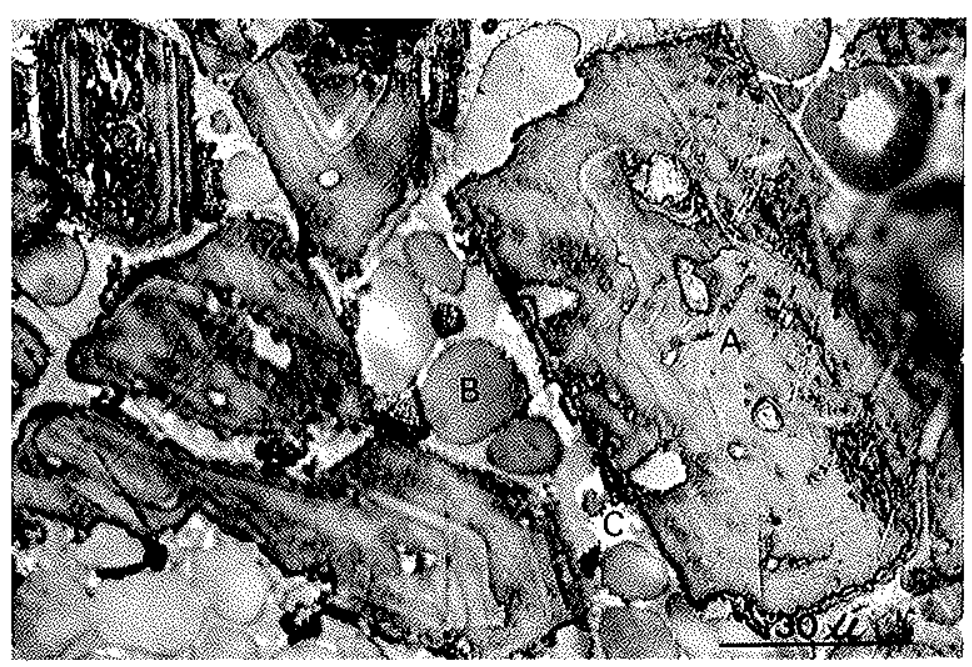

\section{Foto 11 - Clinquer $\mathrm{C}$ - ataque: bóxax $+\mathrm{H}_{2} \mathrm{O}-(40 \mathrm{OX})$ Cristrais zonados de alita (A) e cristais arredondados de belita (B). Temperatura e tempo de clinquerização normal.}

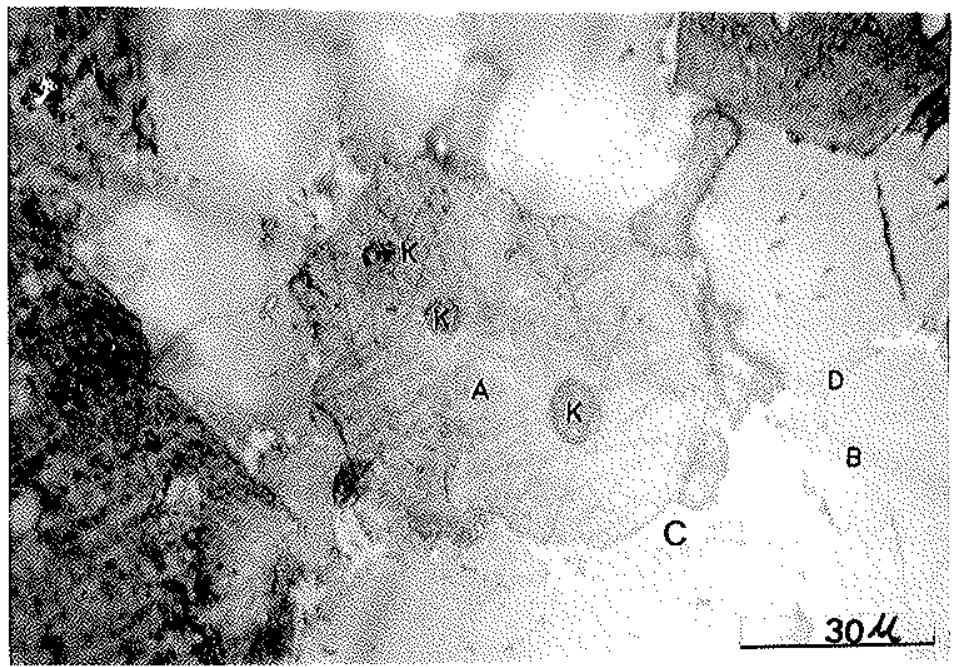

Foto 12 - Glinquex $\mathrm{C}$ - ataque: $\mathrm{H}_{2} \mathrm{O}$ " (400x) Cristal de alita (A) com inclusôes de $\mathrm{CaO}$ livre; cristais arredondados de belita (B) e fase intersticial semi-crissalizada (C). 


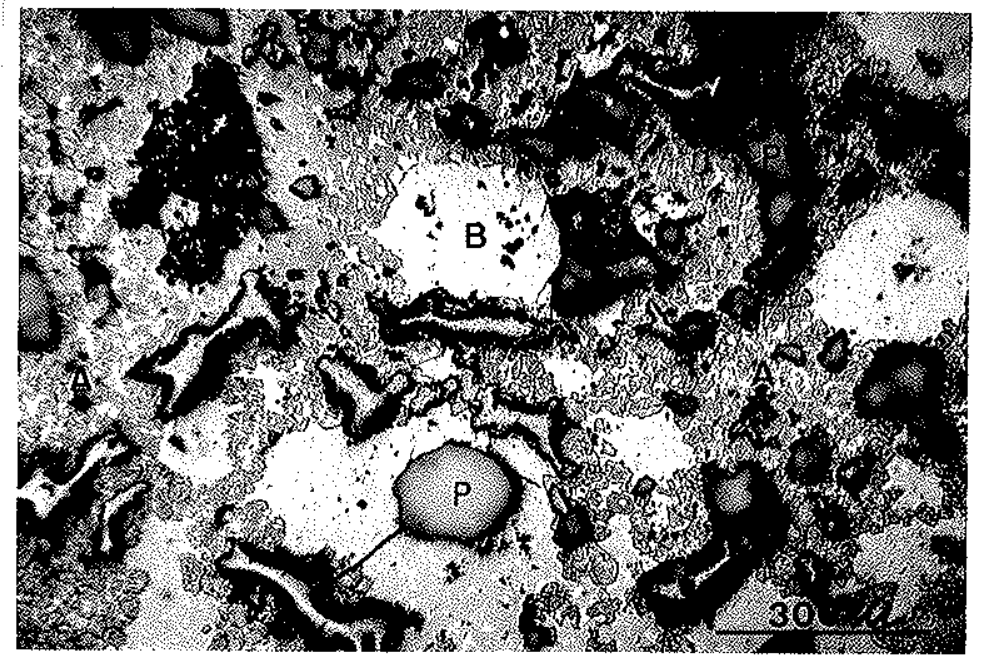

Foto 13 - Clinquer D - ataque: $\mathrm{H}_{2} \mathrm{O}+$ bórax - (50x) Aspecto geral do clinquer comzonas de ali ta (A) e de belita (B), de CaO livre (K) e poros (P). Deficiências de moagem do cru.

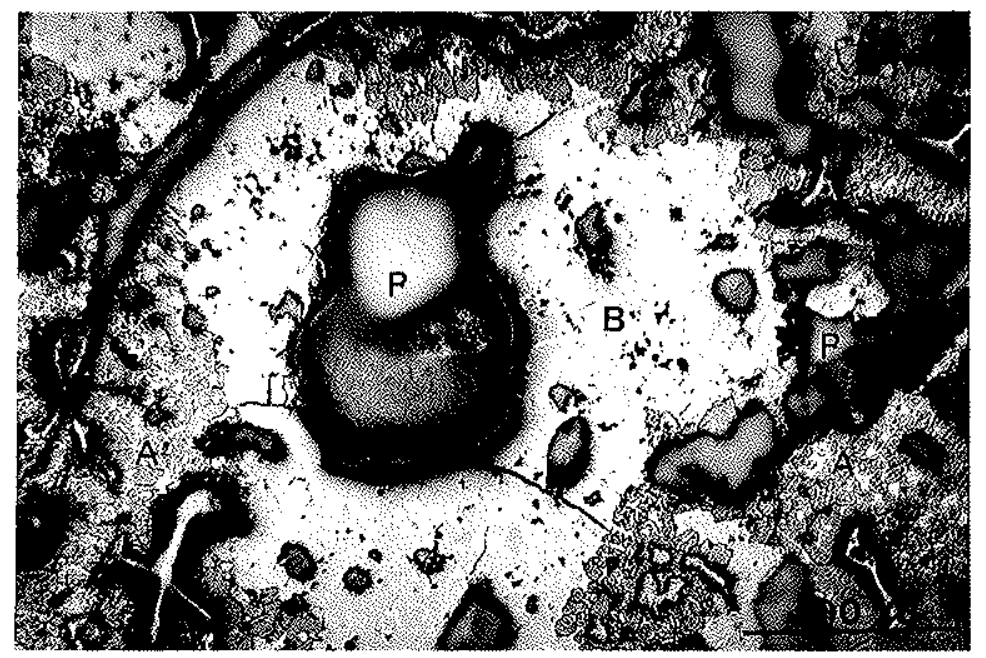

Foto 14 - Clinquer D - ataque: $\mathrm{H}_{2} \mathrm{O}+$ bórax - (50X) Ampla zona belítica $(B)$ com poro $(P)$ na sua parte central, demonstrando granulometria inadequada do cru. 


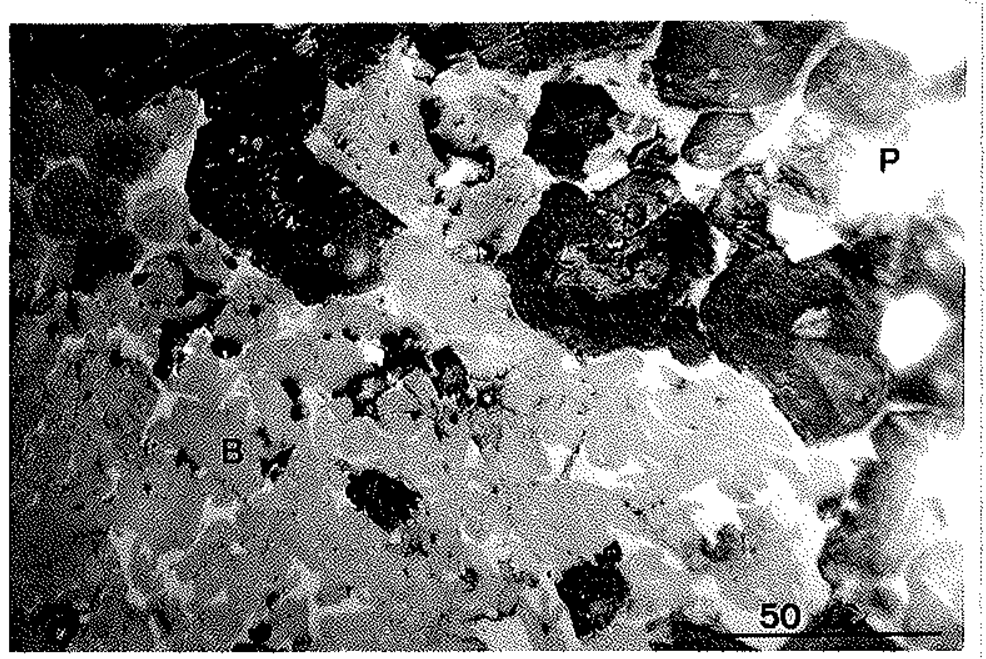

Foto 15 - Clinquer D . ataque: bórax $+\mathrm{H}_{2} \mathrm{O}-(280 \mathrm{X})$ Cristais de alita (A) corroidos e cristais de belita (B) digitados. Resfriamento lento.

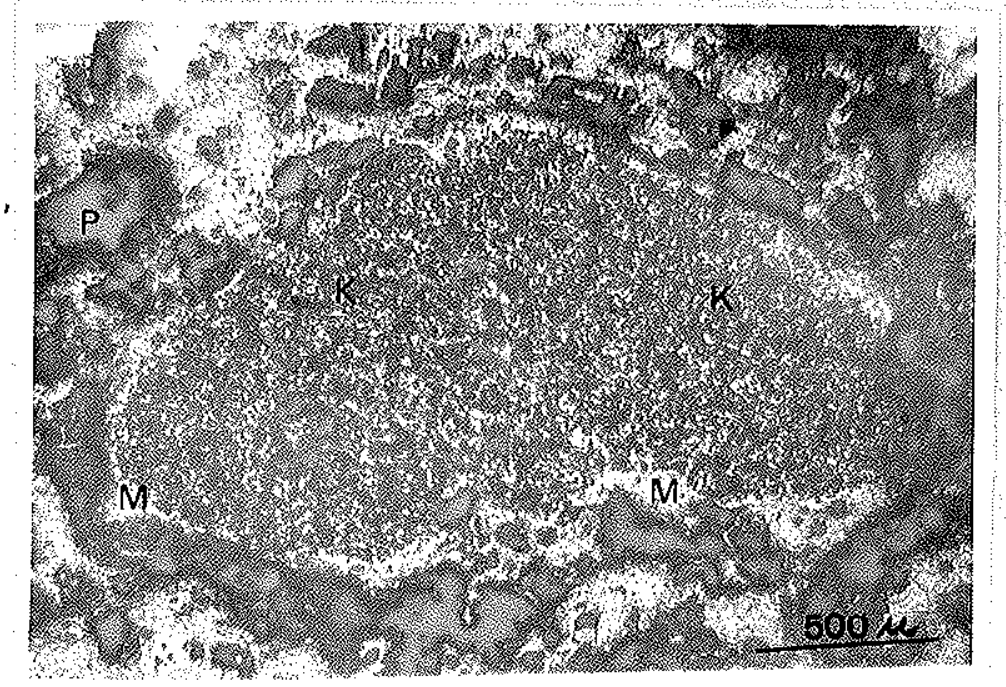

Foto 16 - Clinquer D - ataque: bórax $+\mathrm{H}_{2} \mathrm{O}$ - (20X) Zona maior que 2.000 de CaO livre (K) e periclásio $(M)$, originado de calcáreo do lomútico. Deficiências na moagem do cru. 


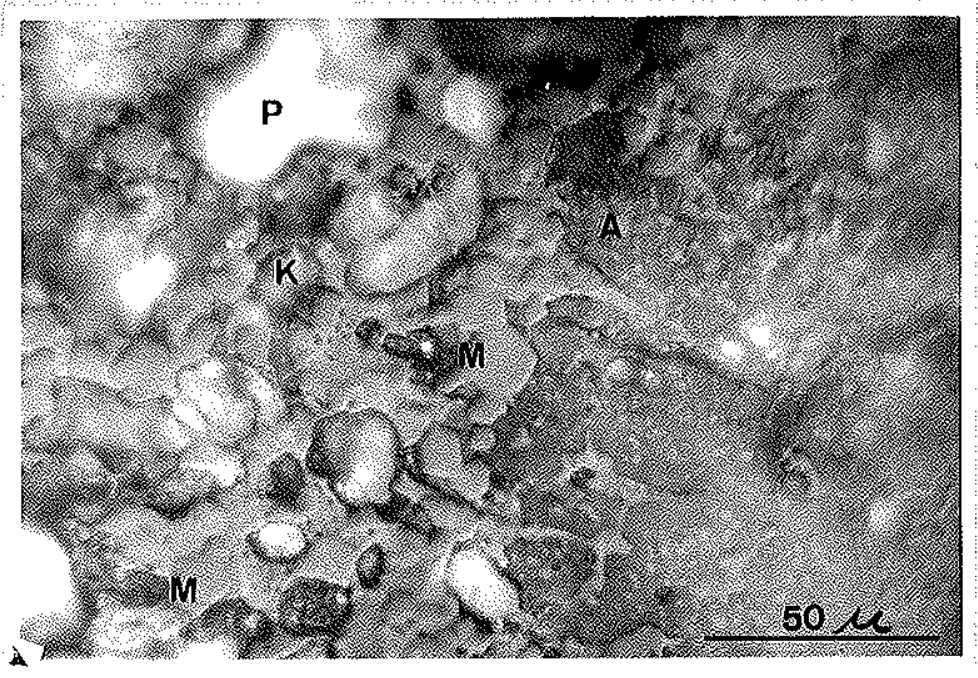

Foto 17 - Clinquer D - ataque: bórax $+\mathrm{H}_{2} \mathrm{O}-(280 \mathrm{X})$ Detalhe da ampla zona de CaOlivre (K) e periclásio $(\mathrm{M})$ da foto 16 , mostrando cris tais de periclásio idiomórfico e desenvolvi dos, junto de cristais arredondados de CaO livre.

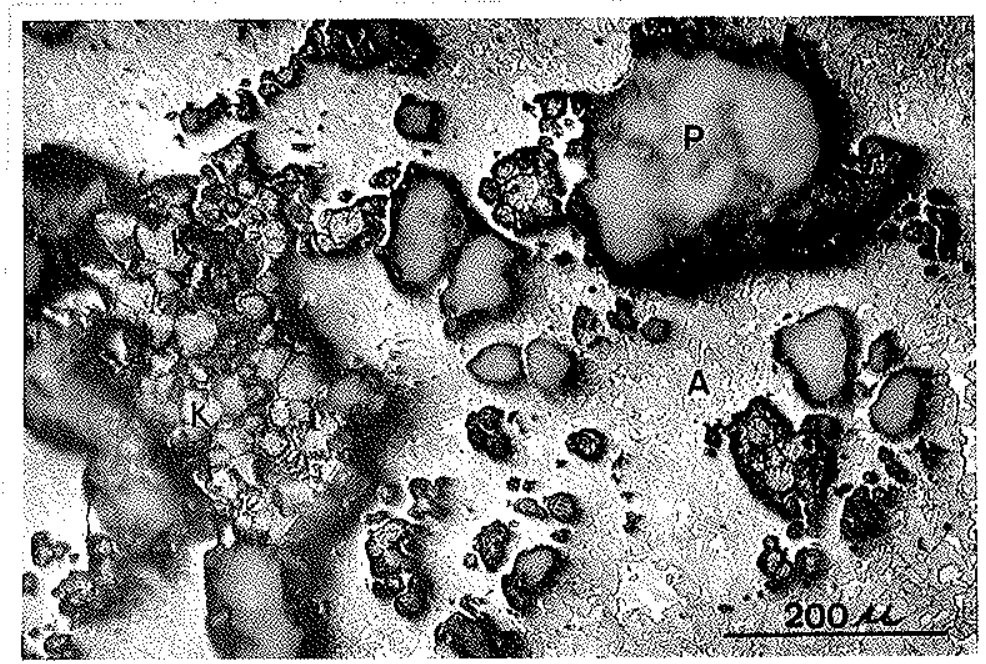

Foto 18 - Clinquer $\mathrm{E}$ - ataque: bórax $+\mathrm{H}_{2} \mathrm{O}-(70 \mathrm{X})$ Aspecto geral do clinquer com zona de CaO livre (K) con forma do grão original de calcáreo. Deficiência na moagem do cru. 


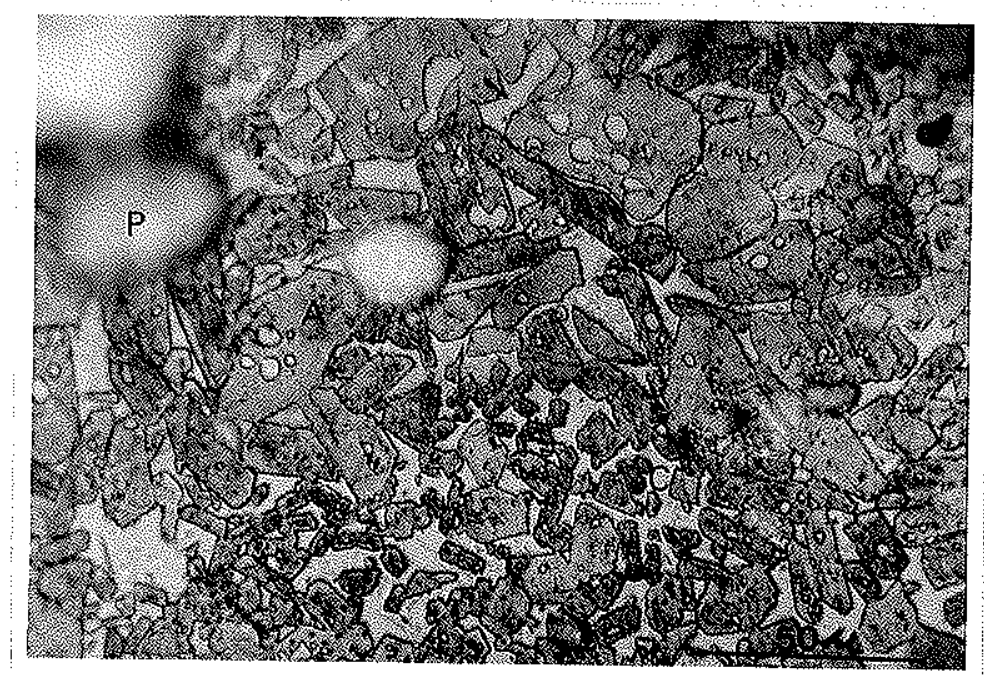

Foto 19 - Clinquer E - ataque: $\mathrm{H}_{2} \mathrm{O}+$ bórax - (280X) Zona de segregação de crišais de alita (A), sendo alguns alongados, indicando tempexatu ra de clinquerização alta.

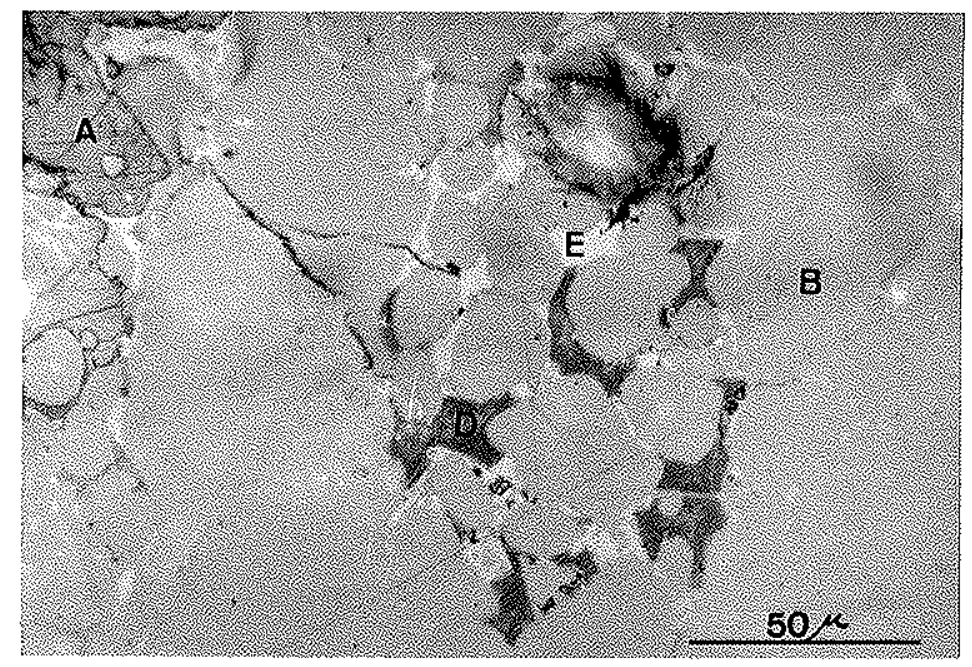

$$
\begin{aligned}
\text { Foto } 20- & \text { Clinquer } \mathrm{E} \text { - ataque: } \mathrm{NaOH}-(280 \mathrm{X}) \\
& \text { Cristais de alita }(\mathrm{A}) \text { de belita }(\mathrm{B}) \text { e aspecm } \\
& \text { to da fase inter sticial cristalizada com cris } \\
& \text { tais de aluminato cálcico retangular }(D) .20 \\
& \text { resfriamento lento. }
\end{aligned}
$$




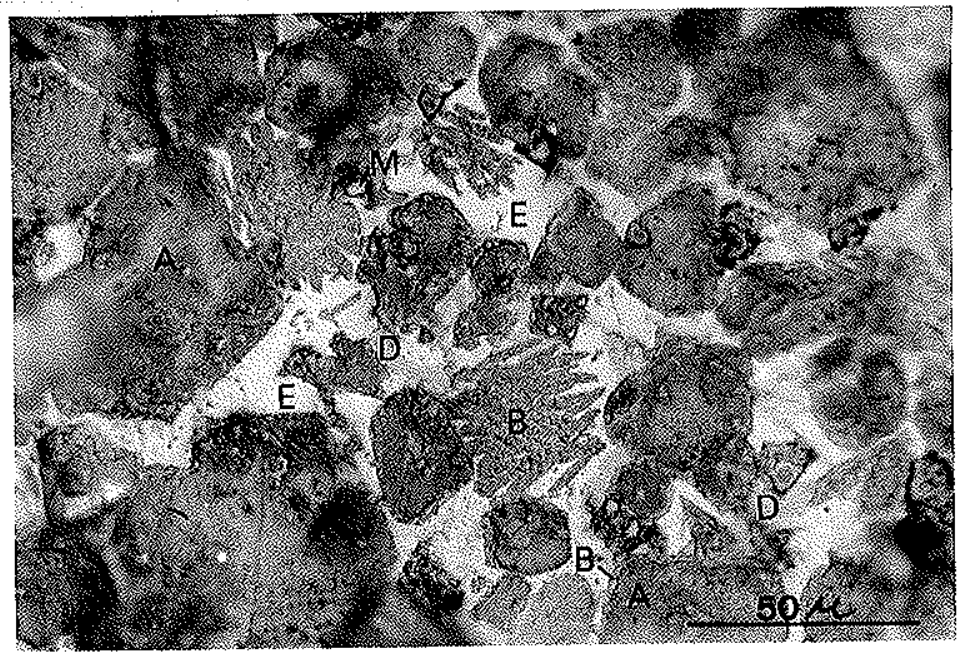
Foto 21 - Clinquer $\mathrm{F}$ - ataque: $\mathrm{HCl}+\mathrm{H}_{2} \mathrm{O}-(280 \mathrm{X})$ Cristais de alita (A) decompostos, cris - tais de belita (B) digitados e fase intersti - ciall cristalizada (C). Resfriamento lento.

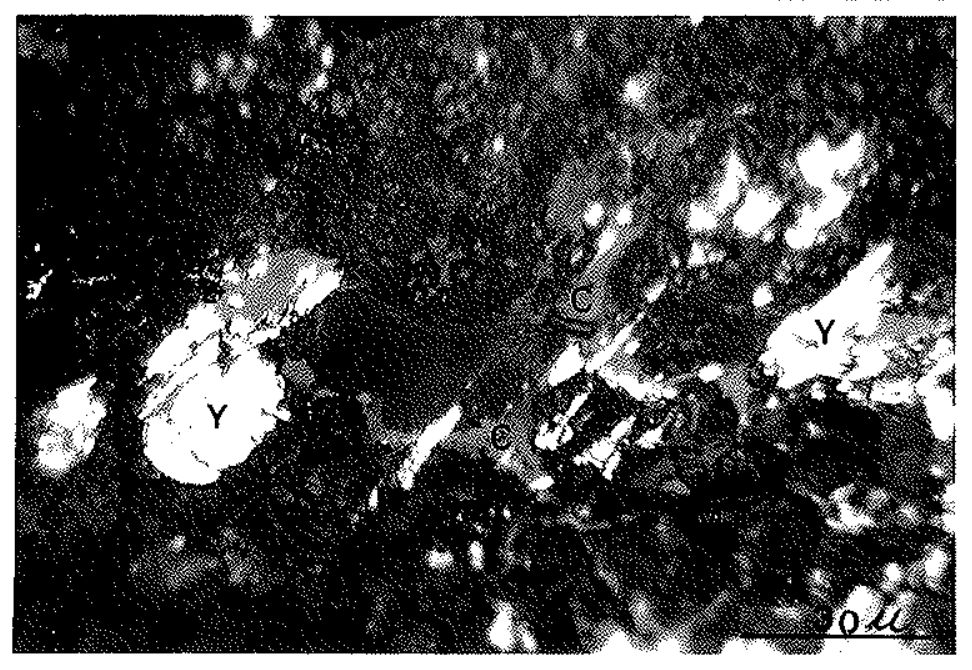

Foto 22 - Clinquer $\mathrm{F}$ - ataque: $\mathrm{H}_{2} \mathrm{O}-(400 \mathrm{X})$ Cristais de alita (A) decompostos, cristais de belita (B), pexiclásio $(M)$ e fase metáli ca $(\mathrm{Y})$. 